\title{
The engineered nanoparticles in food chain: potential toxicity and effects
}

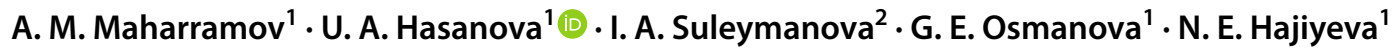

๑ Springer Nature Switzerland AG 2019

\begin{abstract}
Nanomaterials include dispersing materials containing structural elements (grains, crystallites, blocks, clusters, etc.), due to their nano dimensions acquire qualitatively new functional and operational characteristics, offering several biomedical and technical advances over their bulk analogues. Taking into the consideration the fact that the impact of nanoparticles (NPs) to a living organism through the food chain is extremely important and have not been studied in detail yet, in this review we aimed to show the effect of different NPs towards terrestrial food chain, aquatic ecosystem, microorganisms and etc. Understanding and managing the potential risks associated with the use of nanoscale objects serves as a guide for developing new methods, tools, and concepts in order to determine how new engineering nanoparticles will interact with living organisms in the food chain and environmental systems. It is assumed that these methods will fundamentally differ and challenge the existing research and testing methodologies.
\end{abstract}

Keywords Food chain · Engineered nanoparticles · Toxicity · Environment · Ecosystem

\begin{tabular}{|c|c|c|c|}
\hline Abreviation & & $\mathrm{Hb}$ & Hemoglobin \\
\hline $\mathrm{Al}$ & Anxious index & Hct & Hematocrit \\
\hline BALF & Bronchoalveolar lavage fluid & Hpf & High power field \\
\hline ChIF & Chlorophyll fluorescence & HUVECS & Human umbilical vein endothelial cells \\
\hline CNTs & Carbon nanotubes & ICP-AES & Inductively coupled plasma-atomic emis- \\
\hline $2 \mathrm{D}$ & Two-dimensional & & sion spectroscopy \\
\hline DAPI & 4',6-diamidino-2-phenylindole & ICP-MS & Inductively coupled plasma mass \\
\hline 2DG & 2-Deoxy-D-Glucose & & spectrometry \\
\hline DNA & Deoxyribonucleic acid & ICP-OES & Inductively coupled plasma-optical emis- \\
\hline ESR & Erythrocyte sedimentation rate & & sion spectroscopy \\
\hline FE & Field emission & $\mathrm{LDH}$ & Lactate dehydrogenase \\
\hline FitcDx & Fluorescein isothiocyanate-dextran & MC & Macrocycle \\
\hline FSNP & Fluorescent core-shell silica nanoparticles & $\mathrm{MCH}$ & Mean corpuscular hemoglobin \\
\hline FTIR & Fourier transform infrared spectroscopy & $\mathrm{MCHC}$ & Mean corpuscular hemoglobin \\
\hline FW & Freshwater & & concentration \\
\hline GA & Gum arabic & MCV & Mean corpuscular volume \\
\hline GABA & Gamma-aminobutyric acid & MDA & Malondialdehyde \\
\hline $\mathrm{Gl}$ & Germination index & MP & Membrane potential \\
\hline GP \% & Germination percentage & MR & Membrane resistance \\
\hline GSH/GSSG & Glutathione/glutathione disulphide & MSNs & Mesoporous silica nanoparticles \\
\hline
\end{tabular}

$\triangle$ U. A. Hasanova, u.alimammad@gmail.com | ${ }^{1}$ Chemistry Department, Baku State University, Academic Z. Khalilov Str. 23, 1148 Baku, Azerbaijan. ${ }^{2}$ Biology Department, Baku State University, Academic Z. Khalilov Str. 23, 1148 Baku, Azerbaijan.

SN Applied Sciences (2019) 1:1362 | https://doi.org/10.1007/s42452-019-1412-5

Received: 4 August 2019 / Accepted: 1 October 2019 / Published online: 10 October 2019 


$\begin{array}{ll}\text { MTT } & \begin{array}{l}\text { 3-(4,5-dimethylthiazol-2-yl)-2,5-diphe- } \\ \text { nyl-2 h-tetrazolium bromide }\end{array} \\ \text { MWCNTs } & \text { Multi-walled nanotubes } \\ \text { NMR } & \text { Nuclear magnetic resonance } \\ \text { NPs } & \text { Nanoparticles } \\ \text { PAMAM } & \text { Polyamidoamine } \\ \text { PEG } & \text { Polyethylene glycol } \\ \text { RGD } & \text { Tripeptide Arg-Gly-Asp } \\ \text { POD } & \text { Peroxidase } \\ \text { QSIM } & \text { Quantitative spatial information mapping } \\ \text { RBC } & \text { Red blood cells } \\ \text { RGP } & \text { Relative germination percentage } \\ \text { RNA } & \text { Ribonucleic acid } \\ \text { ROS } & \text { Reactive oxygen species } \\ \text { SAS } & \text { Synthetic amorphous silica } \\ \text { SEM } & \text { Scanning electron microscopy } \\ \text { SOD } & \text { Superoxide dismutase } \\ \text { SPIONs } & \text { Superparamagnetic iron nanoparticles } \\ \text { ST II } & \text { See-through medaka } \\ \text { SW } & \text { Environmental salinity } \\ \text { SWCNTs } & \text { Single-walled nanotubes } \\ \text { T-AOC } & \text { Total antioxidation competence } \\ \text { TEM } & \text { Transmission electron microscopy } \\ \text { WBC } & \text { White blood cells } \\ \text { XANES } & \text { X-ray absorption near edge spectroscopy } \\ \text { XRD } & \text { X-raydiffractometry } \\ & \end{array}$

\section{Introduction}

Nanostructures are 1-100 $\mathrm{nm}$ scaled particles and their size defines their physical and chemical properties that sharply differ from the properties of their bulk analogues. Nanoparticles (NPs) due to their size have unique physical and chemical properties and they can form supramolecular ensembles similar to ones widely occurring in nature [1]. Depending on the size, shape, chemical composition, surface, phase state and etc. the nanosized materials are divided into different groups (Table 1). The physical and chemical features of engineered nanosized materials are crucial in term of evaluation of possible risk to the environment and revealing toxicity towards biological systems. The physicochemical properties of NPs need to be thoroughly studied in order to provide the toxicological assay on engineered NPs [2-5].

The latest developments in the nanotechnology led to the widespread of different types of nanosized materials having numerous applications in various fields and at the present more than 1300 nanomaterials are currently available on the different field [6]. They found their application as a constituent of food, cosmetics, furniture, clothing, bottle coatings, opacifiers, microelectronic devices, in SIM cards of cell phones, pharmaceuticals, etc $[7,8]$. According to achievements of nanotechnology over the last decade's, NPs are used in catalysis, oil
Table 1 Classification of nanostructured materials

\begin{tabular}{ll}
\hline Classification of nanostructured materials & Types of nanostructured materials \\
\hline Zero-dimensional NSMs (0D) & Quantum dots \\
One-dimensional NSMs (1D) & Heterogeneous particles arrays \\
& Core-shell quantum dots \\
& Nanolenses \\
& Nanorods \\
& Nanotubes \\
Two- dimensional NSMs (2D) & Nanobelts \\
& Nanowires \\
& Hierarchical nanostructures \\
& Nanoprisms \\
& Nanoplates \\
& Nanosheets \\
& Nanowalls \\
& Nanodisks \\
& Nanoballs (dendritic structures) \\
& Nanocoils \\
& Nanocones \\
& Nanopillers \\
& Nanoflowers \\
& Dendrimers \\
\hline
\end{tabular}


industry, water treatment, fuel additives. Besides, nanofluids are applied as advanced new generation materials and known for their heat transfer performance and thermal properties [9-11]. It is considered that applications of nanotechnology in medicine, especially for targeting drug delivery will able to overcome the problem of noncurable diseases. For developing of successful nanoparticulate system the biodegradation and the rate of drug release are among the crucial factors. It is supposed that the major advantage of NPs is the raising solubility of nanodrugs in an aqueous medium, growing stability and bioavailability delivery in the body and designing the site-specific drug delivery [11-15].

Among the possible route of NPs intake into the body and possible ways of their migration it worth to note the following: inhalation, that is, the intake of NPs by inhaled air through the lungs; intake of water and food containing NPs through the digestive tract; entry of NPs through the skin and mucous membranes; exposure to NPs contaminated surfaces; entry through the gills into the circulatory system of aquatic organisms.

In addition, NPs can enter the human body through targeted exposure, such as injections or other medical, cosmetic, or wellness treatments. Another possible way is constant contact with household items and materials made using nanomaterials. Of particular interest is the possible mechanism for the penetration of nanoparticles through the skin, designed to protect the body from external influences.

In order to investigate the influence of nanoparticles on living organisms, initially, we should know how they pass through into the cells of a variety of organisms such as human, animals or plants, etc. It is important to define cellular uptake of NPs as it helps to understand the mechanism of delivering drugs inside the cell and assess the toxicological consequences [16-18]. Pathway process of NPs to the cell, which called "endocytosis", begins with the interaction of NPs with the external part of the plasma membrane. Forming membrane-bound vesicles, delivering to various specialized vesicular structures, delivering to different intracellular compartments, recycling to the extracellular milieu or delivering across cells are the stages of endocytosis (Fig. 1).

As it is seen from Fig. 2 endocytosis has two types such as pinocytosis (cell drinking) and phagocytosis (cell eating). Firstly, during phagocytosis nanoparticles are recognized by opsonization in the bloodstream before they adhere to the cell membrane. After all these processes nanoparticles are ingested by the cells. In addition, Clathrin-dependent endocytosis, which is called "classic way of cellular uptake", is common in all active mammalian cells. In cases of being devoid of clathrin-dependent endocytosis, clathrin- and caveolae-independent endocytosis

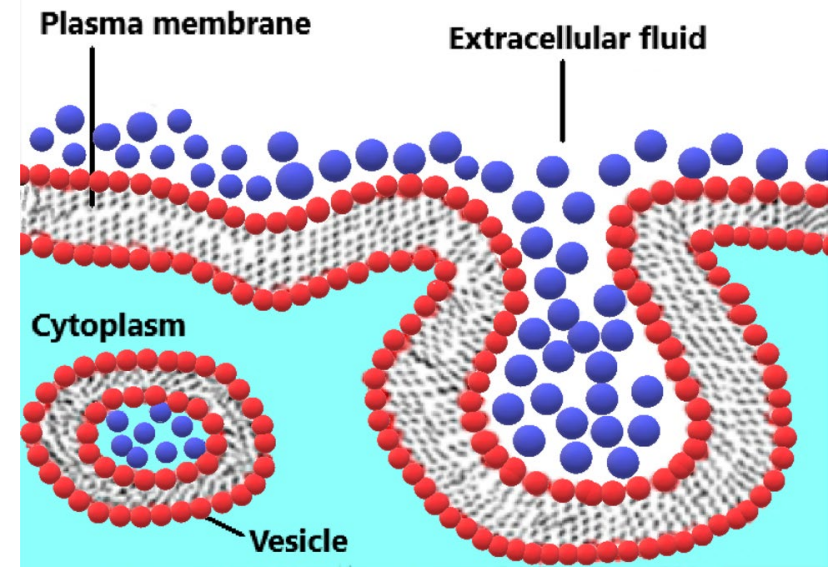

Fig. 1 Cellular uptake and endocytosis (pinocytosis) process

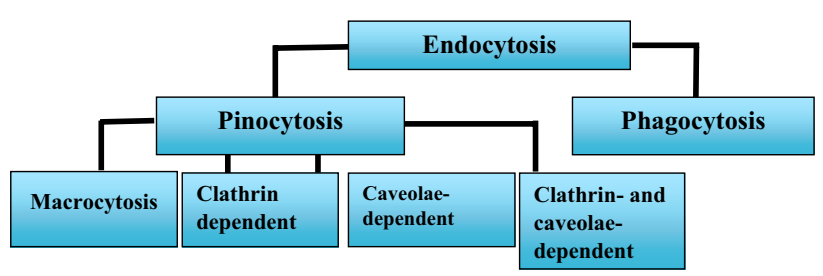

Fig. 2 Classification of endocytosis

happen for entry of a variety of particles which are carried with approximately $90 \mathrm{~nm}$ vesicles $[19,20]$.

The contact of nanoparticles with biological membranes often results in their capture inside the cell using a number of mechanisms-direct or receptor-mediated. Capture ("enveloping" by a membrane) requires the formation of both specific and non-specific interactions with the membrane and it is the result of a dynamic process of particle capture mechanisms and processes that prevent this. Modification of the particle surface by special ligands stimulating receptor-mediated endocytosis. The ecotoxicological and toxicological effects can vary from one type of nanostructures to other, from the different routes of exposure, occurrence in the environment, their quantity, solubility and aggregation state. Among the main characteristics can be mentioned the electrostatic state of their surface, which strongly influence to accumulation status of NPs in the environment. It is estimated that the surface of NPs strongly influences on their toxicity. The NPs with the positively charged surface are considered having higher toxicity [21-24]. NPs can come to contact with living organisms through different routes: incidental release, direct release from industrial enterprises or processes. After release into the environment, they can contaminate the soil and then migrate to the deeper layers and reach groundwater. Furthermore, nanomaterials 
reach an aquatic system through rainwater or wind runoff. Another possible way of occurring of NPs in the environment is the usage of nanotechnology approaches in agriculture. By dint of nano-fertilizers in agriculture, it is possible to enhance plant productivity and increase economic efficiency $[6,7]$.

The main exposure routes are the gastrointestinal tract and respiratory tract [25]. Accumulation of NPs in the living organism can lead to lung injury, cause chronic diseases and serious DNA mutations. It is supposed that target organs for the accumulation of NPs are considered mostly to be spleen and liver $[6,7]$. Nevertheless, it is considered that most of the crystal nanomaterials might transfer into the organism through the inhalation system and easily deliver alveoli [26] In comparison with pulmonary and skin uptake, the intestinal uptake is more detailed described (Fig. 1).

The water-soluble stable NPs can accumulate in the aquatic environment and exposure of NPs to the aquatic food chain in a concentration-dependent way affect to the behaviour of aquatic organisms [1, 27, 28]. In the most studies have been investigated the influence of NPs on the model food chain systems consisting of earthworms, semiaquatic organisms, fishes, invertebrates, algae, plankton, freshwater organisms, amphibians and on the mammals cells $[1,29]$.

The suggested mechanism of the toxic effect of NPs reveals itself in the form of oxidative stress on the living organism that is the response of the biological system by producing of highly reactive particles, consisting of free radicals. Oxidative stress is the imbalance between the formation of reactive oxygen species (ROS) and biochemical mechanisms of repairing and detoxifying of the caused damage. It is considered those general mechanisms of impact of metal-based nanoparticles, carbon nanotubes and fullerenes to living cells is happen by oxidative stress, which finally leads to cell damage. Oxidative stress leads to the formation of free radicals and peroxides, which damage DNA, lipids, and proteins [30]. Carbon nanotubes lead to genotoxic effect by two ways: directly interact with DNA; or indirectly-carbon nanotubes induced oxidative stress and inflammatory reactions [31, 32]. NPs are able to penetrate through the cell membrane and enter into the cell. Once NPs entered the organism they contact with biomolecules (lipids, carbohydrates, and proteins). Among cell compartments, mitochondria are considered as target organelle, which plays a major role in nanoparticle-induced oxidative stress. It is important to define cellular uptake as it helps to understand the mechanism of delivering and interaction of NPs inside the cell. The present review aimed to report of ecotoxicity studies of engineered nanomaterials to model ecosystem; to aquatic organisms including animal and plants, focusing on the mechanism of transferring of nanomaterials in food chain [33-36].

\section{Inorganic nanoparticles}

Thanks to developments in nanotechnology and according to growing interest to the applications of produced nanostructures, different types of inorganic NPs (Fig. 3) and their numerous synthetic routes have been developed in recent years [36]. The inorganic NPs are considered to be the promising materials in the field of drug delivery and diagnostic imaging, catalysis, and development of new electronic devices. For instance, there are plenty of studies dedicated to the application of inorganic NPs in the cosmetics, food industry, environmental contamination control and etc [37]. There are many inorganic NPs based on metal- and nonmetal-containing NPs [38] that are introduced into the ecosystem through anthropogenic route and as well as the result of various processes occurring in nature. For example, the inorganic NPs derived from forest fires, volcanoes eruption, from marine aerosols are found not to exhibit the perceivable toxic effect on the ecological system. The various studies devoted to the distribution of naturally occurred NPs in living organisms reveal that they intensively incorporate into biological structures without any serious toxic effect $[37,38]$. At same time, the anthropogenic nanoscale materials exhibit different physicochemical properties, such as high surface-to-volume ratio in comparison with their bulk counterparts are considered to be not friendly towards environment and biological structures [39-42]. The toxicity of NPs depends on chemical composition, shape, size, particle chelating and surface charge [43] It is extremely important to evaluate the influence of inorganic NPs towards living organisms, as they are the major segments of food chains.

\subsection{Inorganic nanoparticles in the food chain}

Research of biodistribution of NPs in the food chain is very significant in term of revealing of their toxicity and bioassessment [29]. NPs may introduce to food chain through assorted contaminants, which contain these potentially toxic substances [44]. The food chain is an important pathway for investigation intake of NPs to high-trophic-level organisms [45]. The influence of inorganic NPs is explored in several models consisting of various living organisms, such as algal-zooplankton food chain [29]; terrestrial food chain [45]; Chlorella Vulgaris [46]; Arctic polynya ecosystem [47]; mammalian cells [48]; Epinephelus coioides [49]; Eisenia Andrei [50]; Dunaliella tertiolecta [51]; marine food chain [52] and etc. There are many reasons that may affect to NPs transfer in the food chain, and among them, the 


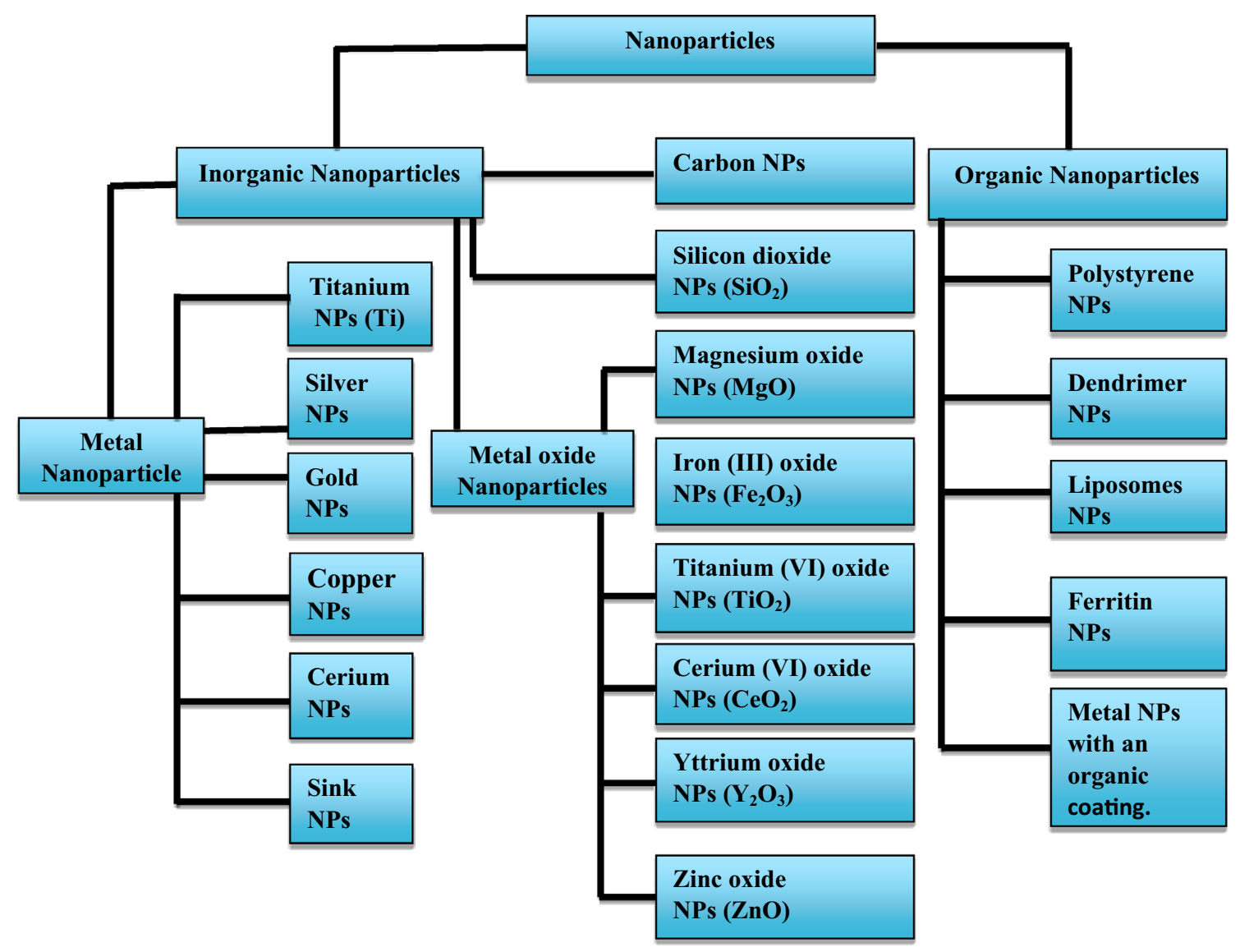

Fig. 3 Classification of nanoparticles

crucial factors are physicochemical properties of NPs, duration of exposure and different route of transfer [53]. Significant processes for tracking the trophic transfer of inorganic NPs are biosorption and bioaccumulation in the food chain [52]. Inorganic NPs enter organisms in the food chain through the soil, water, and feeding. In addition, these NPs may cause the toxic effect through changes of the level of reactive oxygen species, neutron activation, cell, mRNA and DNA damage [44].

\subsubsection{Titan oxide nanoparticles}

The $\mathrm{TiO}_{2} \mathrm{NPs}$ are applicable in the vast majority of skin care products, cosmetics, paints, surface coating. $\mathrm{TiO}_{2}$ have two allotropic forms: rutile and anatase, which show different surface properties, respectively lipophilic and hydrophilic. Both of them have toxic effects, however the toxicity of anatase is more pronounced in comparison with rutile's toxicity [54]. The influence of $\mathrm{TiO}_{2} \mathrm{NPs}$ has been learned mainly on freshwater ecosystems (Daphnia Magna, zebrafish) [53]; terrestrial ecosystems and etc [55].

The main consumers of $\mathrm{TiO} 2$ nanoparticles are children because candies, gums, desserts and beverages were enriched with the high level of $\mathrm{TiO} 2$ nanoparticles due to their optical properties which increase lightness and brightness of food products [56].

$X$. Zhu et al. investigated toxicity, bioaccumulation; biotransformation of TiO2 NPs in freshwater food chain consists of low trophic level organism daphnia and zebrafish-the high trophic level organism. The investigation of the influence of $\mathrm{TiO}_{2}$ on Daphnia Magna showed that the main reason for the toxicity of inorganic NPs is their exposure duration. Authors determined no biomagnification of $\mathrm{TiO}_{2} \mathrm{NPs}$ in dietary intake, but at the same time, they reported that aqueous exposure of zebrafish led to the high-level accumulation of $\mathrm{TiO}_{2} \mathrm{NPs}$ with high bioaccumulation factors [53]. B. Jovanovic et al. reported about enhanced mortality of fish from bacterial pathogens, Aeromonas hydrophila or Edwardsiella ictaluris in the presence of $\mathrm{TiO}_{2} \mathrm{NPs}$. They explained the high mortality by the immunotoxic effect of $\mathrm{TiO}_{2} \mathrm{NPs}$ accumulated mostly in the kidney and spleen of fish. The correlation of depressed immune response towards pathogens due to the presence of $\mathrm{TiO}_{2} \mathrm{NPs}$ firstly reported in this research. Authors concluded that pollution of the environment by $\mathrm{TiO}_{2} \mathrm{NPs}$ could negatively interfere with the marine ecosystem 
due to weakening of resistance against pathogens in fish organisms [57].

Moreover, the impact of $\mathrm{TiO}_{2} \mathrm{NPs}$ investigated in the terrestrial food chain by Miyoko Kubo-Irie et al. They explored the transferring of $\mathrm{TiO}_{2} \mathrm{NPs}$ to the larval midgut of butterfly (Atrophaneura alcinous) through submerging of the root of the host plant (Aristolochia debilis) in the solution containing $10 \mu \mathrm{g} / \mathrm{ml} \mathrm{TiO}_{2} \mathrm{NPs}$. The researchers used X-ray analytical microscopy, transmission electron microscopy, quantitative spatial information mapping (QSIM) technique for determining the accumulation of $\mathrm{TiO}_{2}$ NPs. Experiments reveal that nanoparticles are distributed in the ecosystem from the plant to the larvae and they spread back throughout the environment over larval excrement [55].

S. Amara et al. interrogated the toxic effect of $\mathrm{TiO}_{2} \mathrm{NPs}$ in the organism of adult Wistar rats by means of inductively coupled plasma-atomic emission spectroscopy (ICP-AES) and X-ray diffractometry (XRD). The intraperitoneal injection of $\mathrm{TiO}_{2} \mathrm{NPs}$ ( $20 \mathrm{mg} / \mathrm{kg}$ body weight) led to increasing of the anxious index (Al) and pathology in the liver tissues in comparison with control. The authors observed accumulation of $\mathrm{TiO}_{2} \mathrm{NPs}$ in the liver, lung, and brain and increasing of the platelet count [58].

Researches show that the main routes of TiO2 NPs introduction in the living organisms occur through feeding and via environmental exposure and their toxicity is associated with chronic influence on immune cells and subsequent inflammation.

\subsubsection{Magnesium oxide nanoparticles}

The main application areas of MgO NPs are electronics, catalysis, ceramics, antibacterial agent, food additive, fire retardant and corrosion inhibitor [59,60]. Due to various application fields, MgO NPs can spread in the environment, aquatic ecosystem, terrestrial food chain and etc. MgO NPs can pass to levels of the food chain through water, soil, air, and a diet containing MgO NPs. For these reasons, the evaluation of their toxicity, uptake, accumulation, and transfer in the food chain is quite important in order to assess the possible risks caused by exposure of living organisms to MgO NPs.

$\mathrm{S}$. Ge et al. investigated the cytotoxic effects of $\mathrm{MgO}$ NPs on human umbilical vein endothelial cells (HUVECs) in vitro by MTT assay, DAPI staining analysis, NO release, and total antioxidation competence (T-AOC) assay. Authors noticed that at low concentration of MgO NPs the cytotoxicity is not observed, whereas at high concentration (higher than $500 \mathrm{mg} / \mathrm{ml}$ ) MgO nanoparticles inhibited the growth rate in comparison with control. Authors indicated that magnesium oxide nanoparticles reveal toxicity and the relative growth rate slow down at lower particle size, higher concentration and expanding of exposure time. At the same time, the surprise was that after 24 exposure the NO and T-AOC content significantly increased 3.29 and 1.22 correspondingly $[59,61]$. This may be caused by producing of the ROSs as result of MgO NPs impact and as response led to increasing of T-AOC content, which serves as effective antioxidant defence system decreasing the level of ROSs and their metabolites [59].

The investigation ecotoxic properties of MgO NPs are important for determining the dangerous effects of NPs towards aquatic organisms. Daoud Ali et al. have studied the ecological influence of magnesium oxide NPS in freshwater pond snail Radix leuteola L. (R. luteola) by dynamic light scattering and field transmission electron microscope. They observed DNA damage and increasing of enzyme level at higher concentration of MgO NPs [62, 63]. M. Ghobadian et al. investigated the toxicity of $\mathrm{MgO}$ NPs taken at a wide range of concentration on zebrafish (Danio rerio). The paper reports of the considerable toxic effect of MgO NPs towards the hatching rate, survival, malformation, and cellular apoptosis. Authors speculated that the toxic effect of MgO NPs may be caused by the increasing level of intracellular ROSs [63].

Kesmati M. et al. analyzed the influence of MgO NPs compared to bulky $\mathrm{MgO}(\mathrm{cMgO})$ in the interaction between their effects and anxiolytic effect, induced by exercises. The authors noted that bulky MgO did not show a significant effect on anxiety and locomotor activity in contrast to MgO NPs. The anxiolytic effect of $\mathrm{MgO}$ NPs can be caused by regulating glutamatergic neurotransmission and GABAergic neurotransmission [64-66]. The lack of anxiolytic effect of MgO NPs injected during exercises, in authors' opinion, may be explained by decreasing of concentration of ionic Mg in the cell due to binding with lactate. Authors concluded that MgO NPs could be prescribed as $\mathrm{Mg}$ supplement at hypomagnesemia caused by intensive exercises [67].

Leila Jahangiri et al. evaluated anticonvulsive effect under the sway of MgO NPs comparatively to bulky $\mathrm{MgO}$ on strychnine-induced convulsion model in diabetic and non-diabetic male albino mice, due to there is a correlation between diabetes and idiopathic generalized epilepsy. They determined that bulky MgO didn't cause changing death time after the injection to experimental and control male albino mice groups. MgO NPs prohibited convulsion effect and changing death time after strychnine injection on normal and diabetic mice groups. Authors speculated that the effect of MgO NPs may be explained with higher activity of NPs and direct interaction with the central nervous system or through peripheral mechanisms [68]. 


\subsubsection{Zinc oxide nanoparticles}

The ZnO NPs find its application in the field of sensors, in the electrical and optical devices, dye-sensitized solar cells, varistors, chemical absorbent and etc [69-71]. In order to better understand the expected and unexpected effects that may be caused by the introduction of $\mathrm{ZnO}$ NPs into the ecosystem the detailed studies impact of ZnO NPs toxicity should be conducted [72].

Sung-Ji Yoon et al. investigated negative effects and bioaccumulation of ZnO NPs over the roots and shoots growth and reproduction of soybean plants in different concentration $(0,50$, or $500 \mathrm{mg} / \mathrm{kg})$ in a soil microcosm. The authors observed a reduction of surface area and volume of root and shoot biomass and negative effect on reproduction in soybean plants subject to ZnO NPs taken in high concentration [73]. Another study regarding the toxic effect of $\mathrm{ZnO}$ NPs compared to $\mathrm{Zn}^{2+}$ ions towards some soil microorganisms and plants was reported in [74] ZnO NPs spiked soil caused $100 \%$ mortality of the ostracod $\mathrm{H}$. incongruent, after 6 days of exposure, whereas soluble $\mathrm{Zn}^{2+}$ ionic form exhibited only $21 \%$ toxicity effects. Authors considered that sharp differences in the higher toxic effect of ZnO NPs compared with soluble $\mathrm{Zn}^{2+}$ can be linked with nano dimensions and corresponded chemical and physical characteristics of ZnO NPs.

In another interesting study [75] was reported about the toxic effect of $\mathrm{ZnO} N$ Ps on developmental processes of embryonic/larval zebrafish and reveal the transcriptional responses using microarray analysis. ZnO NPs toxicity was similar to the $\mathrm{Zn}^{2+}$ ions toxicity taken in comparable concentration, at the level of embryonic/larval development. However, malformations, which included edema of the pericardium, the tail and the yolk sac as a consequence of the impact of ZnO NPs were induced by overexpression ogfr 12 and cyb5d 1 genes, and significantly altered the expression of genes associated with cytokine receptor and immune system. The results of this insight study reveal that the immune responses related to $\mathrm{ZnO}$ NPs were significantly different in comparison to the ionic form of $\mathrm{Zn}$.

The impact of engineered ZnO NPs on the physiological performance and survival of the marine mussel was studied in [76]. Based on the results obtained from the research it is possible to predict the potential impact and better understanding of the toxicity of engineered $\mathrm{ZnO}$ on populations of coastal marine species, which is very important in term of maintaining water quality and supporting biodiversity.

As it has seen the appropriate evaluation of the toxicological impact of $\mathrm{ZnO}$ NPs on the living organism is a very important task in term of further safe application of engineered NPs without harmful effect on the environment.

\subsubsection{Iron-containing nanoparticles}

The iron containing nanoparticles have high potential in application in the following fields such as: biomedicine [77-79], cellular labeling [80, 81], magnetic separation [80, 82], tissue repair, hyperthermia [83], magnetic resonance imaging, magnetically guided drug delivery [80, 84], molecular diagnostics [85] and catalysis [86, 87]. There are numerous reports about influences of magnetic iron nanoparticles towards biological system that have been learned through plant, animal models [73]. The impact of iron-containing NPs was observed in the marine food chain, their accumulation in organs and tissues, structural and ultrastructural damage, and activation of detoxification processes in larvae and adults were detected [88-90].

As we know the artificial and natural supramolecular objects and nanostructures obey the self-assembling principle. The authors of [91] exploited this idea and studied the syderophoric properties of nanostructures based on magnetite NPs and diazacrown ether that can play the role of both-ionophore antibiotic and iron chelating agent. It is known that gram-negative microorganisms need the higher concentrations of iron ions, so they secret the special low-molecular compounds that are able selectively to coordinate the iron ions from extracellular space and by means of syderophoric channels to drag them into the bacterial cell. At the same time, the crown ether thanks to its ionophoric properties are able to disrupt the cell membrane potential and cause the death of bacteria. The results of experiments demonstrated that prepared magnetite-crown ether nanostructures have a significant antibacterial effect on gram-negative microorganism Klebsiella spp. and Escherichia coli, and even were able to inhibit their growth in biofilm almost in all concentrations. Ulviyya Hasanova et al. investigated the synthesis of the hydroxyl-containing azacrown macrocycle (MC), which is able to imitate natural siderophores properties. On the basis of synthesized MC were prepared the supramolecular ensembles with magnetite nanoparticles, loaded by cephalosporin antibiotics. NMR, mass-, FTIR spectroscopy methods, scanning electron microscopy (SEM), XRD analysis methods were used to investigate synthesized MC and to analyze the morphology of prepared nano-ensembles. Results of experiments carried by prepared nanostructures tested on gram-negative Escherichia Coli and gram-positive Staphylococcus aureus showed that nanostructures significantly increase the antimicrobial effect of cephalosporins and decrease their MIC [92].

The authors of another interesting research devoted to functionalizing the surface of magnetite nanoparticles with cefotaxime and ceftriaxone antibiotics also reported of the influence of prepared nanostructures on gram-negative microorganisms Klebsiella spp., of 
Enterobacteriaceae, and gram-positive bacteria Staphylococcus aureus. According to the result of their investigation, the binding of antibiotics with $\mathrm{Fe}_{3} \mathrm{O}_{4}$ nanoparticles led to enhancing of antibacterial effect of cephalosporins, due to so-called "Trojan horse" principle. The bacteria are not able to resist the antibiotic action because of the molecules of antibiotic-associated with magnetite NPs and easily penetrate through cell membrane [93].

It is considered that there are several types of approaches for exploring the toxic effect of NPs on plants. One of the most interesting biophysical methods of testing the effects of NPs on plants in vivo is Chlorophyll fluorescence (ChIF). A.M. Maharramov and et al. reported of ChIF quenching induced by the iron oxide $\left(\mathrm{Fe}_{3} \mathrm{O}_{4}, \mathrm{Fe}_{2} \mathrm{O}_{3}\right)$ and aluminium oxide $\left(\mathrm{Al}_{2} \mathrm{O}_{3}\right)$ nanoparticles in vivo experiments. They used fluorescence spectrophotometry for determining excitation and emission spectra of intact leaves of Elodea. Results showed that the intensity of ChIF reduced in the $\mathrm{Fe}_{3} \mathrm{O}_{4}$ and $\mathrm{Al}_{2} \mathrm{O}_{3} \mathrm{NPs}$ solution on the light. The toxicity of $\mathrm{Fe}_{2} \mathrm{O}_{3}$ depends on the exposure period and the increasing of NPs concentration slightly affects the plant. The experiment showed that $\mathrm{Fe}_{3} \mathrm{O}_{4}$ and $\mathrm{Al}_{2} \mathrm{O}_{3} \mathrm{NPs}$ enter into the cell and might reduce chlorophyll content in the plant leaves. Thus, for assessment of the impact of the nanoparticles ChIF can serve as a reliable, noninvasive indicator of photosynthetic processes in plants. The results of this experiment indicate that it is possible to use ChIF spectra for determining the toxic effect of nanoparticles to plants [94].

I.S. Ahmadov et al. investigated the uptake and movement of magnetite NPs by the ESR method in elodea plants. The authors for the first time studied the rootstem-leaves redistribution of magnetite NPs in elodea plants and supplied direct proof for biotransformation and bioaccumulation of Fe NPs in the plant by means of ESR spectroscopy. Stem, root or leaves of elodea exposed to an aqua solution of superparamagnetic iron oxide nanoparticles (SPIONs) with concentration $12.9 \mathrm{mg} / \mathrm{ml}$. The results of the experiments showed that NPs may get into root tissues or cells and transport to stem and leaves. The concentration and exposure period strongly affect the distribution and accumulation of SPIONs in the plant organs. Authors concluded the feasibility of detection of SPIONs by ESR method even in the tissue of plants (in symplastic or apoplastic) when they interact with organic materials and sintered. It considered that short distance migration of SPIONs is favoured. However, the prolongation of the exposure period allows detecting NPs for longer distance migration; SPIONs have been found in leaves of elodea even when the plant was exposed to a very diluted solution of SPIONs. The result of this study supplies the good evidence that ESR spectroscopy of paramagnetic NPs is a beneficial method for detecting uptake, accumulation, and transport of nanoparticles [95].

Sergey Bombin et al. learned the influence of maghemite NPs $\left(\mathrm{Fe}_{2} \mathrm{O}_{3}\right)$ on Arabidopsis thaliana taken at different concentration ( 3 and $25 \mathrm{mg} / \mathrm{l}$ ). They found that the character of this influence is concentration dependent. Impact of iron oxide nanoparticles showed a reduction of root and seedling length, inhibition of seed germination at higher concentration [96]. Tapan K. Jain and et al. learned biodistribution, clearance, and biocompatibility of iron oxide magnetic nanoparticles in the rats. The accumulation of iron NPs was observed in higher extends in the liver and spleen, then in brain, heart, kidney, and lung. The analyses of the results of this investigation have not shown long-term changes in the liver enzyme levels or inducing of oxidative stress [97]. The results of this study reveal that iron NPs are easily metabolized and biotransformed by the organism, which makes these structures biocompatible and opens wide perspectives to application in biomedical fields. J. Li et al. have learned the translocation and physiological effects of magnetic iron oxide in the corn plant. They found that at higher concentration the magnetic iron oxide nanoparticles ( $\mathrm{g}-\mathrm{Fe}_{2} \mathrm{O}_{3} \mathrm{NPs}$ ) influence on decreasing of corn root length, whereas the exposure at lower concentration (20 mg/l) led to (11.5\%) root elongation and improved seed germination index and vigour index. By means of fluorescence and transmission electron microscopy (TEM) was shown the migration of $\mathrm{Fe}_{2} \mathrm{O}_{3} \mathrm{NPs}$ from the epidermis to the endodermis leading to accumulation of NPs in the epidermis of root vacuoles. The authors concluded that a better understanding of factors influencing on NPs impact will help in the further application of ironcontaining NPs as nanofertilizer [98].

Dr Kristin R. Di Bona has learned toxicity and biodistribution of iron oxide nanoparticles in pregnant CD-1 mice. The article reports that the toxic effect of magnetite NPs depends on the NPs surface charge. They determined that both positively and negatively charged $\mathrm{Fe}_{3} \mathrm{O}_{4} \mathrm{NPs}$ easily penetrate through placenta and cumulate in the liver tissues of the fetal organism, but the toxic effect revealed the positively charged NPs resulting by the increasing of the fetal deaths. Authors concluded that, when designing the new NPs, applicable in biomedicine field, the surface charge should be considered as one of the important factors for risk assessment [99].

\subsubsection{Gold nanoparticles}

Gold nanoparticles (Au NPs) are used as biosensors, therapeutic agents [100], and promising carriers of biomolecules [101-103]. In vivo experiments reveal that application of some chemicals without a thorough evaluation of potential toxicity can bring to high risk of ecosystem 
contamination, thus it is necessary to study the possible route of accumulation of Au NPs in the food chain [104].

Jared S. Bozich et al. investigated the toxic effects of negatively and positively charged $\sim 4-5 \mathrm{~nm}$ gold NPs (AuNPs), functionalized with a wide range of organic molecules towards Daphnia Magna during short term and full life cycle. The positively charged Au NPs were found to be more toxic than the negatively charged Au NPs. Both of them showed different effects depending on the functional group on the reproduction ability of Daphnia Magna. The results of this study provide firm evidence that the toxic effects and the sustainability of NPs depend on surface chemistry. The high affinity of positively charged Au NPs to negatively charged cell surfaces may be among the possible reasons of higher toxicity in comparison with negatively charged Au NPs [105]. Authors also mentioned that the aggregation state in extra and intracellular media also influence on toxicity of engineered Au NPs. Authors emphasize that this fact can explain the higher toxicity of smaller sized Au NPs, enabling to easier introducing and interacting with cells organelles with further disruption of main metabolic pathways [106].

Chen et al. explored in vivo inflammatory effects, organ toxicity and distribution of $21 \mathrm{~nm}$ gold nanoparticles when injected intraperitoneally in adipose tissue male mice. They found that Au NPs mostly accumulated in the abdominal fat tissue, reducing the fat mass and inhibiting the inflammatory effect. At the same time, Au NPs did not show valid toxicity in liver and kidney tissue of mice. Authors suppose that Au NPs may be used for treating obesity and obesity-related diseases as a therapeutic agent [107].

In another study was evaluated the toxic effect, bioaccumulation, and contamination of Au NPs in the experimental model algal-zooplankton food chain (Fig. 4). The analysis showed that Au NPs entered the body of a zooplankton grazer (Daphnia Magna) by two ways; with contaminated phytoplankton food (Ankistrodesmus falcatus) and directly from the water. Au NPs was detected in the gut of Daphnia by bright field microscopy. At the same time, together with accumulation there was not

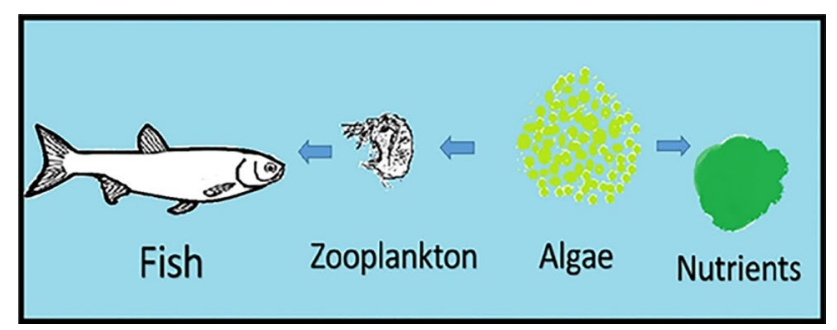

Fig. 4 Algae-zooplankton-fish food chain determined the toxicity and behavioural changes in Daphnia Magna [29].

Jason M. Unrine et al. investigated the trophic transfer of Au NPs by means of soil media from Earthworms (Eisenia fetida) to bullfrogs (Rana catesbeina). Authors determined the accumulation of Au NPs in bullfrog organs such as liver, kidney, muscle, intestine, stomach, and spleen, explaining it as a result of "trophic filter". In their opinion, Au NPs trophic transfer most probably occurs from one organism to another through the food chain and it is more efficient than through direct contact of an organism with NPs [108].

In another approach authors determined trophic transfer of Au NPs in the terrestrial food chain, consisting of model organisms Nicotiana tabacum L. cv Xanthi and Manduca sexta (tobacco hornworm). Jonathan D. Judy et al. paid attention to biomagnification and trophic transfer of Au NPs among terrestrial food chain depending on $\mathrm{Au}$ NPs size. Authors supposed that plant uptake and trophic transfer of Au NPs was linked with the structure of cell membrane and size of NPs [104].

\subsubsection{Rare and rare earth metal}

Rare and rare earth metal nanoparticles may find their application in electronics, luminescent materials, fuel additives, catalysts, coating, biomedicine, and energy because of its low-redox potential, radical scavenging activity, high ionic conductivity, and enhanced UV absorbing properties $[45,109,110]$. Furthermore, rare and rare earth metal NPs also can release into the environment by means of various above-mentioned routes $[44,52,53,111]$.

Jason C. White et al. have studied the accumulation and trophic transfer of $\mathrm{CeO}_{2}$ nanoparticle in the terrestrial food chain which consists of zucchini (Cucurbita pepo L.), crickets (Acheta domesticus), and wolf spiders (family Lycosidae). The accumulation of $\mathrm{CeO}_{2} \mathrm{NPs}$ was determined in the flowers, leaves, stems, and roots of zucchini by inductively coupled plasma mass spectrometry (ICP-MS). The authors emphasize that many unanswered questions arise from this study, among them the mechanism of accumulation and transport, the physical state of these nanostructures in the subcellular space, the concentration dependence and the real danger to the human organism in the case that these nanostructures enter the food chain where the top consumer is the human [112].

The authors of review [110] devoted to the biological application of $\mathrm{CeO}_{2} \mathrm{NPs}$ pointed that due to the quick conversion of $\mathrm{Ce}$ ions from +3 oxidation state to +4 they can mimic enzymatic functions and serve as an antioxidant during redox reactions occurring in living organisms. These antioxidative effects were described in numerous studies that reported experiments carried in vitro in simple buffer solutions. However, further 
investigation of this topic demand in vivo experiments in biological media in order to evaluate the $\mathrm{CeO}_{2} \mathrm{NPs}$ toxic effects.

Sanghamitra Majumdar et al. learned the impact of cerium oxide nanoparticles in terrestrial food chain consisting Kidney bean plants (Phaseolus vulgaris var. red hawk), Mexican bean beetles (Epilachna varivestis), spined soldier bugs (Podisus maculiventris). They observed biomagnification and bioaccumulation of $\mathrm{CeO}_{2}$ in Kidney bean plant tissues (roots, stems and leaves) and larval tissues of Mexican bean beetles and spined soldier bugs by means of inductively coupled plasma-optical emission spectroscopy (ICP-OES). Authors concluded that intentional or accidental release of $\mathrm{CeO}_{2} \mathrm{NPs}$ can cause pollution of cultivation crops, areas and the trophic transfer and accumulation of Ce NPs in food chain [44]. Fate and phytotoxicity of $\mathrm{CeO}_{2}$ nanoparticles have been examined in lettuce by Xin Gui et al. They used ICP-MS and X-ray absorption for determining $\mathrm{CeO}_{2} \mathrm{NPs}$ in lettuce plants. The authors determined the influence of $\mathrm{CeO}_{2} \mathrm{NPs}$ at different concentration interval ( $100 \mathrm{mg} / \mathrm{kg}$ and $1000 \mathrm{mg} / \mathrm{kg}$ ) on lettuce plant. The toxic concentration for plant growth was observed at $1000 \mathrm{mg} / \mathrm{kg}$ whereas concentration ranges at about $100 \mathrm{mg} / \mathrm{kg}$ enhance the plant growth. The results of experiments demonstrate that at high concentration of $\mathrm{CeO}_{2} \mathrm{NPs}$ the activity of Superoxide dismutase (SOD), Peroxidase (POD) and Malondialdehyde (MDA) was depressed. Authors explain the NPs toxicity by the bioconversion of $\mathrm{Ce}^{4+}$ into $\mathrm{Ce}^{3+}$ ions [113].

Yuhui Ma et al. have examined the toxicological and biological effects of $\mathrm{La}_{2} \mathrm{O}_{3}$ and $\mathrm{CeO}_{2} \mathrm{NPs}$ to cucumber (Cucumis sativus) plants. The experiments show that $\mathrm{La}_{2} \mathrm{O}_{3}$ NPs have inhibition effect on the root, shoot elongation and biomass at different concentration, whereas in case of $\mathrm{CeO}_{2} \mathrm{NPs}$ there was no phytotoxicity on cucumber at all tested concentrations ( $2 \mathrm{mg} / \mathrm{l}-20 \mathrm{mg} / \mathrm{l}-2000 \mathrm{mg} / \mathrm{l})$. For the investigation of distribution and speciation of these NPs authors used synchrotron-based micro X-ray fluorescence microscopy and $X$-ray absorption spectroscopy. Authors assume that higher phytotoxicity of $\mathrm{La}_{2} \mathrm{O}_{3} \mathrm{NPs}$ is connected with better dissolution and thus easier penetration, binding and movement insight of plant organs [114].

Yunyun Chen et al. studied the influence of yttrium oxide NPs as well as their uptake, gathering, circulation and concentration mapping in cabbage (Brassica oleracea). The results obtained from the research show that while yttrium oxide NPs easily uptake by roots they did not operatively mobilize and transferred through the leaves and cabbage stem. Authors indicate that synchrotron dual-energy $\mathrm{X}$-ray micro-tomography is the good choice for determining of yttrium oxide-NPs accumulation with $3 \mathrm{D}$ visualization in the cabbage root, but there are some limitations of application of this method. They notice that it is not capable to detect the fate of Yt biotransformations in the plant organism [115].

M.A. Ramazanov et al. investigated the interaction of $\mathrm{ZrO}_{2}, \mathrm{Al}_{2} \mathrm{O}_{3}$ and Ni NPs with plant cells' plasmatic membrane, affecting the activity of $\mathrm{H}+$-ATPase and redox system. Results showed that according to the NPs type, duration of exposure and concentration the electrical parameters of plasmatic membrane changes. It was found that $\mathrm{ZrO}_{2}, \mathrm{Al}_{2} \mathrm{O}_{3}$, and Ni NPs strongly depolarize membrane potential and significantly affect $\mathrm{H}+$-ATPase electron-proton pumps activity. However, it was shown that NPs do not strongly influence the redox type of proton pumps. Electrophysiology studies show that endocytosis migration of NPs across the plasma membrane of plant cells, make changes in the function and structure of plasma membrane and it depends on nanoparticles size, concentration and exposure time. The exposure of plant cells with aqueous solutions of NPs leads to decrease of plasmatic membrane potential (MP) and membrane resistance (MR). The effect of NPs in green cells depends on media light-dark regime. The results of experiments show that while NPs interact with the plasmatic membrane of cells the $\mathrm{H}+$-ATPase proton pump is more sensitive to the NPs exposure rather than redox type of proton pump. Nanoparticles change the mineral nutrition of plant cells and the plasmatic membrane damage can play a key role in cell death [116]. So, as it can be seen the assessment of the impact of rare and rare earth metal NPs on the environment is very essential because these NPs can easily spread through all trophic levels and reveal the toxic effects on representatives of the food chain.

\subsubsection{Copper-containing nanoparticles}

Copper oxide NPs (CuO NPs-1-100 nm) have various application fields such as catalysts, magnetic storage media, solar energy transformer, solar cells and lithium batteries, semiconductors and field emission, gas sensors, biosensor in drug delivery, electronic chips, and heat transfer nanofluids. Due to their unique properties (chemical efficiency, photovoltaic and photoconductive properties, melting temperature, surface effect) and wide application area there is a need for clarification of the impacts of Cs measured the negative influences of $\mathrm{Cu}$ NPs on growth and development of juvenile carp with biochemical, histological and two-dimensional (2D) proteomic analysis [117]. The non-lethal effects of CuO NPs were studied by Villarreal et al. on Mozambique Tilapia (Oreochromis mossambicus) at 0.5 and $5 \mathrm{mg} / \mathrm{l}$ concentration in the constant freshwater (FW) and in environmental salinity (SW). This study showed that $\mathrm{CuO}$ NPs caused sublethal changes: antioxidant enzyme activities, metal-binding protein mRNA and grow of $\mathrm{Cu}^{+2}$ ions concentration in liver and 
gills of fish, increasing opercular ventilation rate, GSH/ GSSG ratio (glutathione/glutathione disulfide). However, it was emphasized that these effects were environmental dependent and more pronounced in the environmental salinity [118].

S. Nations et al. studied the influence of CuO NPs on Xenopus laevis to determine the level of growth and development during the 14 days (Subchronic) and 47 days (Chronic). In the period of Subchronic exposure was observed the highest mortality rate at concentrations-0.625, 1.25, and $2.5 \mathrm{mg} / \mathrm{l}$. However, they indicate that high-level mortality during chronic exposure was observed at $0.3 \mathrm{mg} / \mathrm{l}$. The results of experiments with CuO NPs taken at different concentrations revealed that body length of tadpoles was much longer than controls at $0,625 \mathrm{mg} / \mathrm{l}$ or fewer concentrations, whereas at higher concentrations the total body length of tadpoles was less in comparison with the control group during subchronic exposure. During the chronic exposure, total body length of tadpoles was recorded bigger than in the control group [119]. In another research were studied the ecotoxicological influence of various concentration CuO NPs and bulk $\mathrm{CuO}$ on Lemna minor. C.O. Ogunkunle et al. accurately estimated the biotransformation, accumulation and toxic effects of Cu NPs in cowpea (Vigna unguiculata) by X-ray absorption near edge spectroscopy (XANES). The powder of $\mathrm{Cu}$ NPs was introduced into soil and the accumulation of $\mathrm{Cu}$ NPs observed in all organs plant in the stem, leaves, and roots of cowpea $[120,121]$. Singh et al. evaluated the Cu containing NPs on the environment $[113,122,123]$.

Y.R. Gupta et al. investigated the influences of Cu NPs on juvenile carps (Cyprinus carpio) taken at two concentrations $/ / / /(20$ and $100 \mathrm{mg} / \mathrm{l})$. They observed considerable increasing of the level of reactive oxygen species (ROS), superoxide dismutase and glutathione-S-transferase in the kidney, liver, and gills at exposure group in comparison with the control groups. In this study changes of plant growth, chlorophyll content, antioxidant defence enzyme activities (catalase, peroxidase, superoxide dismutase activities), and malondialdehyde content. They observed accumulation of high level of reactive oxygen species and the more pronounced toxic influence of CuO NPs in comparison with bulk $\mathrm{CuO}$. The authors supposed that this is due to the releasing of $\mathrm{Cu}^{2+}$ in the culture media that was estimated to be $50 \mathrm{mg} / \mathrm{l}$. The evaluation of CuO NPs toxicity on hydrophytes is very important because of hydrophytes is an essential part of the marine and freshwater ecosystems [117].

\subsubsection{Silver nanoparticles}

There are numerous studies describing of unique chemical, physical and pronounced antimicrobial properties of silver nanoparticles (Ag NPs) [124-126] and the possibility of their application as anticancer agents [127], water removers [128] optical sensors, for treatment of wounds and etc. Besides, Ag NPs have been widely used for food and food packaging materials thanks to the antimicrobial properties. It is the reason for transferring into the food and then could be ingested by people. At the same, some studies regarding assessment of the AgNPs toxicity revealed the necessity to investigate the aspects of negative impacts of these NPs on the food chain and environment [127-131].

The toxicity and accumulation of Ag NPs on freshwater larvae of Chironomus and fish Danio rerio was investigated by M. Asztemborska et al. The introducing of these NPs into the organism of top consumer-fish occurs by feeding them with freshwater larvae preliminarily exposed to Ag NPs. In this article, authors consider the application of neutron activation as one of the most appropriate methods for detection of accumulation of NPs. Authors emphasized that the transfer of NPs through food led to higher accumulation of Ag NPs compared when they enter into the living organism by consumption of NPs soluble in the water [132]. Y. J. Chae et al. carried out the comparative analysis of the effect of Ag ions and Ag NPs on Japanese Medaka (Oryzias latipes) [133]. The results of the study show that Ag NPs affect the DNA and changes the level of mRNA. Additionally, accumulated Ag NPs cause histological changes in the liver tissue of fish. Ag ions also cause metallic detoxification processes in the liver of Japanese Medaka. Researchers defined that both of them have toxic effects on fish, however, the toxic impact of Ag NPs was higher than that of Ag ions $[133,134]$.

In another study transfer and toxic influence of Ag NPs in different concentrations were evaluated on terrestrial food chain consisting of earthworm (Eisenia Andrei) and Collembola (Lobella sokamensis). The soil preliminarily was treated with an aqueous solution of Ag NPs for transferring of NPs to the body of earthworm. Then the Collembola was feeding with a treated earthworm. Results of the study show that at low concentrations of Ag NPs the earthworm was not affected and as consequences there was observed the low accumulation of Ag NPs in Collembola, whereas at high concentrations they resulted with death of earthworm juvenile and correspondingly led to the higher level of NPs accumulation in Collembola and consequently to reducing of Collembola locomotion [50, 135].

Oukarroum et al. explored the toxicity of Ag NPs with the aim of evaluation of their influence on the aquatic ecosystem, consisting of green algae, Chlorella vulgaris, and Dunaliella tertiolecta. According to the results of the study, there were observed the negative effect of Ag NPs on both of them that was explained by the raising of the level of reactive oxygen species. Additionally, researchers defined 
that Ag NPs have a strong influence on chlorophyll content and viable algal cells [51].

\subsubsection{Silica nanoparticles}

Last times the interest towards synthesis and application of silica NPs is growing day by day. There are a lot of reports about the application of mesoporous silica nanoparticles (MSNs) as optical devices, drug delivery systems, fillers catalyst, adsorbents, in vouro-imaging and biomedical field. Due to the expanding of possible impact and release of $\mathrm{SiO}_{2} \mathrm{NPs}$ into the environment, their toxicity towards living organisms should be clarified and assessed [136-138].

Hofmann T. et al. examined the prenatal toxic impact of synthetic amorphous silica (SAS) nanoparticles during the gestation of Wistar rats. Pregnant Wistar rats were exposed to various concentration $(100 ; 300 ; 1000 \mathrm{mg} / \mathrm{kg}$ body weight per day) of SAS NPs through the oral direction. Researchers identified fetal and placental weights, numbers of corpora lutea, live and dead fetuses. According to the result of research the all concentrations of SAS NPs led to no maternal or embryo-fetal toxic effect on fetuses and no alteration at placental or fetal weights [139]. In another investigation was evaluated the toxic effect of fluorescent core-shell silica nanoparticles (FSNP) taken at a different concentration to zebrafish (Danio rerio) embryos. K. Fent et al. assessed morphological alterations, hatching time and success. Nevertheless, they observed no differentiation hatching success and time, no mortality. FSNP accumulated on the chorion of the zebrafish eggs. The results of the investigation show that FSNP did not cause evident alteration and toxicity at $0.0025-200 \mathrm{mg} / \mathrm{l}$ concentration on early life stages of zebrafish (Danio rerio) [140].

The toxic impact of stable and monodisperse amorphous $\mathrm{SiO}_{2} \mathrm{NPs}(25 \mathrm{~nm}$ ) was evaluated on living Hydra vulgaris (Cnidaria). Researchers observed paralysis of the gastric zone, animal morphology differentiations, enhancement of apoptotic and collapse cells, a decrease of the epithelial cell proliferation rate. Despite these changes, Ambrosone et al. emphasized that $\mathrm{SiO}_{2} \mathrm{NPs}$ not caused lethal toxicity. Authors considered that Hydra is able to adapt to high doses of $\mathrm{SiO}_{2} \mathrm{NPs}$ and adjust its homeostasis [141].

Chenxi Wei et al. investigated the toxic influence of $\mathrm{SiO}_{2}$ nanoparticles (NPs) and bulk $\mathrm{SiO}_{2}$ (BPs) suspensions on chlorophyll content and growth of Scenedesmus obliquus. The results of experiments revealed that the toxic effect of $\mathrm{SiO}_{2} \mathrm{NPs}$ at 50,100, and $200 \mathrm{mg} / \mathrm{l}$ concentration was accompanied by a reduction of photosynthetic pigment content. They determined that $\mathrm{SiO}_{2} \mathrm{BPs}$ have not toxic effects under $200 \mathrm{mg} / \mathrm{l}$ in contrast to the $\mathrm{SiO}_{2} \mathrm{NPs}$. Authors supposed that the sorption of $\mathrm{SiO}_{2} \mathrm{NPs}$ with algal cells surface was the possible reason for the toxicity of $\mathrm{SiO}_{2} \mathrm{NPs}$ on aquatic ecosystem [142].

Krishna Priya et al. explored the influence of silica NPs taken at various concentrations on the representative of the aquatic environment such as freshwater fish Labeo rohita during $96 \mathrm{~h}$. Researchers observed the alteration of haematological (haemoglobin $(\mathrm{Hb})$, hematocrit $(\mathrm{Hct})$, red blood cells (RBC), white blood cells (WBC), mean corpuscular volume (MCV), mean corpuscular haemoglobin (MCH) and mean corpuscular haemoglobin concentration (MCHC) values), ion-regulatory (plasma sodium ( $\mathrm{Nap})$, potassium (Kp) and chloride (Cl) levels and $\mathrm{Nap} / \mathrm{Kp}$ ) and enzymological (ATPase activity in gill) parameters in the tested group. Authors concluded that changes of these parameters caused by toxicity of $\mathrm{SiO}_{2} \mathrm{NPs}$ lead to physiological stress and are able strongly to influence on the health conditions of the aquatic organisms [143].

So, some researchers consider silica NPs as biocompatible with minimal toxicity towards living organisms, whereas the results of other studies point to the pronounced toxic effect of these NPs. The more detailed studies regarding assessment of silica NPs toxicity is required, in order to evaluate the possible impact of engineered silica containing NPs in some applications.

\subsubsection{Carbon-based nanomaterials in the food chain}

Due to the exceptional physicochemical, electronic properties and possibilities of the surface engineering of carbon-containing nanostructures they have very broad application fields. They are considered to be promising materials for drug and gene delivery, automotive and aviation industry, cosmetics, electronics, in the environmental and agricultural sectors. Scientists try to improve the potential of carbon-based material in their wastewater filtration systems. According to broad application fields and as consequences the possibility of the releasing of these nanostructures in the ecosystem there is a huge demand to learn the influence of carbon-containing nanomaterials on food chain, plant and animal organisms [144-151].

Graphene consists of single layers of $s p^{2}$ hybridized carbon atoms, and the distance between the layers is $0.142 \mathrm{~nm}$. Owned to its nanosized structure graphene is a material with high thermal stability and mechanical strength [150]. Graphene widely used as gas and biosensors, field emission (FE) displays, Li-ion battery, and handheld devices and etc [152].

Carbon nanotubes consist of $s p^{2}$ hybridized carbon atoms forming hexagonal and pentagon perfectly ordered structure. Carbon Nanotubes (CNTs) are wrapped layers of graphene divided into two groups depending on the numbers of layers: single-walled nanotubes (SWCNTs) and multi-walled carbon nanotubes (MWCNTs). SWCNTs have 
the diameters ranging from 0.6 to $2.4 \mathrm{~nm}$ and MWCNTs with diameter from 2.5 to $100 \mathrm{~nm}$. SWCNTs have three subclasses such as armchair; zigzag; chiral structures [148-150]. Carbon nanotube have broad perceptivities to be used as carrier for drug delivery, biomedical applications, catalyst, bio- and chemical sensors and etc [153, 154].

J. K. Kim et al. investigated the toxicity and influence of graphene nanoplates at different concentrations $(0.12$, 0.47 , and $1.88 \mathrm{mg} / \mathrm{m}^{3}$ ) using inhalation system on the base of graphene nanoplates on male Sprague-Dawley rats during 28 days. The existence of graphene in the air and biological media was followed through the transmission electron microscopy. Researchers did not observe pathology in the lung during the exposure time. Result of the investigation shows that graphene caused no meaningful enhancement in inflammatory cells, inflammatory markers and considered to reveal the low toxicity [155].

In contrast with the layered structure of graphene, the fullerenes consist of 60 carbon atoms in the $s p^{2}$-hybridized state having a spherical shape. The most stable and symmetric representative of fullerenes family is fullerene $C_{60}$ $\left(C_{n}\right.$ clusters $\left.n>20\right)$. The surface of fullerenes is comprised of pentagons and hexagons [150]. The functionalized fullerenes can find application in biomedicine (medicinal agents), as fuel and solar cells, hydrogen gas storage, fullerene-based sensor and etc.

The toxic impact of fullerenes $\left[\mathrm{C}_{60}, \mathrm{C}_{70}\right.$, and $\left.\mathrm{C}_{60}(\mathrm{OH})_{24}\right]$ learned on embryonic zebrafish by Usenko et al. Researchers observed considerable increasing the level of malformations, pericardial oedema, and mortality in the tissues of embryonic zebrafish. In accordance with results of the study of the toxicity of engineered $C_{60}$ and $C_{70}$ fullerenes were found that $\mathrm{C}_{60}(\mathrm{OH})_{24}$ fullerenes revealed lower toxicity compared with non-engineered fullerenes. $\mathrm{C}_{60}(\mathrm{OH})_{24}$ fullerenes caused no differentiation apoptosis in embryonic cellular in contrast to the $C_{60}$ fullerenes [156].

M. Revel et al. estimated the toxic effects, bioavailability, sediment existence, possible impurities and term of exposure of single-walled carbon nanotubes (SWCNT) taken in various concentration $(0,10,32,100,320$, and $1000 \mathrm{mg} / \mathrm{l})$ towards ecosystem-freshwater amphipod, Hyalella Azteca. They observed no mortality in tested organisms that were exposed to SWCNT taken at 10-40 mg/l concentration interval, but the accumulation of SWCNT occurred in the gut of freshwater amphipod. The exposure of Hyalella Azteca to $320 \mathrm{mg} / \mathrm{l}$ concentration of SWCNT led to their mortality [157]. S. Youn et al. investigated the influence of SWCNTs suspended in gum Arabic $0.023 \%$ and $0.046 \%$ GA) on Pseudokirchneriella subcapitata with biochemical and spectroscopic techniques during $96-\mathrm{h}$ algal bioassays and long-term studies. Researchers determined quantitative (algal biomass) and qualitative (morphology) changes of $P$. subcapitata caused by SWCNTs. They reported that there was not observed growth reduction of $P$. subcapitata at exposure to the $0.01-0.05$ ppm SWCNT in the $0.023 \%$ $\mathrm{GA}$, whereas at higher concentrations the SWCNT revealed high toxicity [158].

The influence of various concentration $(10,50,100$ and 200 ppm) MWCNTs were studied by Pilevar et al. on Cichorium intybus $L$. They observed phytotoxicity of $10 \mathrm{ppm}$ of MWCNTs on Cichorium intybus $L$. that reveal itself as the decrement of relative germination percentage (RGP), germination index $(\mathrm{Gl})$, germination percentage $(\mathrm{GP}, \%)$. MWCNTs had not to influence plumula length, radicle length, seedling fresh and dry weight and vigour index [151].

\section{Organic nanoparticles}

Organic NPs regarded as another largest group of nanomaterials. The history of synthesis and application of organic NPs is not so long in comparison with inorganic NPs. Most of the approaches to produce and investigate the inorganic nanomaterials are not applicable to organic NPs, according to the fact that properties of organic materials (such as lower sublimation and melting point, crystalline structure, etc.) sharply differ from the ones of inorganic NPs. Organic NPs composed of organic compounds (lipids, polymer, carbohydrate, DNA, RNA, proteins and dendrimers) have larger sizes compared to inorganic NPs [159]. Size of organic particles plays a determinative role in their applications throughout many fields such as optoelectronics, biomedicine and environmental science [160]. Thanks to their unique properties they investigated mainly in drug designing and delivery, food, and food processing industry, electronics, agriculture, defence, fermentation technologies, chemical industries and etc [161].

\subsection{Organic nanoparticles in the food chain}

It is well known that the bioavailability, mobility and biological fate of NPs depends on their physical-chemical characteristics, shape, charge, size and etc [162-164]. The bare nano-sized particles when introduced in organism are supposed to be covered with biomolecules by means of non-covalent and covalent interactions. The biomolecules in the biological fluid, such as peptides, proteins, and carbohydrates and etc., bind to the surface of the NPs, forming a corona [165-169]. The compositions of these coating depend on size, surface chemistry of NPs and strongly influence the dynamic properties of NPs $[167,168$, 170]. The proteins in the NPs corona can affect aggregation tendency [170-172], cause change or loss their function [173]. 
Previous studies show that engineered NPs can be released in the environment, soil, atmosphere and water (oceans, lakes) through sewage plants, aerial deposition and waste handling $[173,174]$. Organic NPs can insert into organism directly (passage across gills or external surface epithelia) or indirectly (through inhalation system or digesting intake), through the food chain from one organism to another $[175,176]$. The higher trophic levels of the food chain can be exposed to NPs through lower trophic levels [177]. For example, the polystyrene NPs can be transferred to crucian carp (Carassius carassius) by food chain route [178-181] consisted of three trophic levels, including algae (Scenedesmus sp.), zooplankton (Daphnia Magna), and crucian carp (Carassius carassius) [182].

Over the last years, the use of organic NPs in consumer goods enormously raised, but it should be noted that there is a gap of statistical and practical data about their impacts on human health and ecosystem function. For example, the big concern related to the increasing amount of plastic material waste products at ecosystem and it is claimed that after a while they convert to nanoscale particles, which may have harmful effects on living organisms when degraded [183-186].

\subsubsection{Polymeric nanoparticles}

Polymeric NPs are solid particles with $10-1000 \mathrm{~nm}$ size made of biocompatible and biodegradable polymers. There are crucial demands towards the properties of polymers used in preparation NPs for biomedical applications; they should be non-toxic, non-antigenic, biodegradable and biocompatible. Particularly, most promising drug carriers are considered to be polymeric NPs made of different synthetic (polylactides, poly(alkyl cyanoacrylates)) [187-190] and natural polymers (gelatin, albumin, chitosan, sodium alginate) [191-193]. Although, there are several chemicals, physical and biological barriers for drugs to reach the closed areas of organism, it is believed that natural and synthetic polymer-based nanocarriers have tremendous potential for targeting drug delivery systems, enabling to pass the blood-brain barrier and using for diagnosis and treatment of brain disorders.

Polysaccharide and protein particles mainly used as nanocarriers as they are able to reduce drug's adverse effects and toxicity [194]. Owing to progress in polymer science and technology, polymeric NPs have many applications at many other areas such as photonics, conducting materials, biotechnology, electronics, sensors, pollution control and solving of environmental issues [195-200].

Some polymeric NPs occur in the environment naturally and considered as prominent biomolecules, which have distinguishing features such as balancing the biocompatibility, stability, biodegradability, and functionality of nanocarriers [201]. According to this, carefully designed and appropriately surface-functionalized nanocarriers on the base of carbohydrate molecules, they are able to serve as some effective therapeutics for hardly treatable diseases. Thanks to their availability on a large scale, welldefined structure, high water solubility, biodegradability, and low aggregation, carbohydrates have a wide range of applications. Besides their role in biological signalling, carbohydrates also have other biological functions, including energy storage, protection of cell organelles, modification of the properties of peptides or proteins, etc., which might provide additional advanced properties [202]. Nowadays there is a great interest in the use of carbohydrates as biomimetic functional molecules for the engineering of NPs surface. The investigation carried by D.C.Kennedy showed that monosaccharide, coating of silver NPs, modulates cellular uptake and decrease their toxicity. Galactose and mannose-coated NPs were significantly less toxic to both neuronal-like cells Neuro-2A and hepatocytes, compared to particles functionalized with glucose, ethylene glycol or citrate. Observed toxicity was strongly correlated with intracellular oxidative stress, measured as protein carbonylation, but it does not strongly affect the cellular uptake [203].

A.M. Maharramov et al. investigated new water-dispersible nanostructure-based superparamagnetic iron oxide nanoparticles (SPIONs) coated by 2-Deoxy-D-Glucose (2DG). In the molecule of 2DG, the hydroxyl group of second carbon is replaced with the hydrogen atom. Since cancer cells require more energy they admit $2 \mathrm{DG}$ as a glucose molecule. 2DG-the glucose analogue blocks the glycolytic pathway in cancer cells, and thus the biological activity of prepared NPs has been observed by growth inhibition of colorectal cancer cell lines. This research shows that SPIONs coated by 2DG could be used for targeting delivery and reduces the toxicity of pristine 2DG [204-206].

The main flows by means of which NPs release to the environment is wastewater, sewage sludge, and waste incineration of products containing polymeric NPs [207]. In these regards, the investigations devoted to the evaluation of the toxicity of engineered synthetic organic NPs towards representatives of different trophic levels: bacteria, plants, aquatic and terrestrial organisms are among actual environmental problems [208].

\subsubsection{Polystyrene nanoparticles}

The NPs derived from polystyrene mainly found in marine debris degrades slowly and generated small ranged particles, which easily consumed by wildlife [209]. The authors of $[210,211]$ studied the possible route of styrene NPs introduction into top consumer through the food chain. They found out that these NPs are cumulated into the 
tissue of the brain, liver, blood, muscles, testis by means of direct transfer through skin and gills. Additionally, nanoparticles can form complexes with substances in natural media and are entered to fish through the food chain. Therefore, the results of the investigation of polystyrene NPs impact on living organisms claim that they effect particularly on behaviour, metabolism, and physiology on the top consumer. The creation of simplified model food chain can assist to understand and assess the possible toxicity of engineered organic NPs towards the aquatic animals and plants $[182,186,210]$. K. Mattsson et al. investigated the effects of polystyrene NPs on Crucian carp (Carassius carassius) by introducing $24-27 \mathrm{~nm}$ sized particles in their diet. The behaviour of fish was recorded during the 62 days and at the end of the experiment, they were accurately weighed and measured. The magnetic resonance spectroscopy (NMR) was applied for the determination of changes in the metabolism of test and control groups of fish. In order to reveal the behaviour differences in the control and test groups of fish, have been examined the motion picture that showed that test fishes become less active and energetic due to slow down of the metabolic processes they gathered to swam together. Additionally, it can be clearly seen that morphology of brain tissues differ in these two groups. After feeding off them with polystyrene NPs the test fishes brain tissue becomes heavier, swollenlooking and fluffy in texture [179]. T. Cedervall et al. investigate the impact of commercially manufactured polystyrene NPs to Crucian carp by adding $24 \mathrm{~nm}$ nanoparticles to their diet in the laboratory model of food chain composed of three trophic levels, including algae (Scenedesmus sp.), zooplankton (Daphnia Magna), and Crucian carp (Carassius carassius).The lipoproteins are essential for the fat metabolism and when spherical polystyrene NPs were introduced to fish they bind with fat-carrying apolipoproteins apoA-I, that in turn affect their metabolism and behaviour. Researchers incubated polystyrene NPs with serum collected from Crucian carp (Carassius carassius), Bleak (Alburnus alburnus), Rudd (Scardinius erythrophthalmus), Tench (Tinca tinca), Pike (Esox esox), and Atlantic salmon (Salmon salar) for identifying proteins that are able to bind to these NPs in fish serum. The mass spectrometry analysis was used for determination of polystyrene NPs in fish serum. The results showed that these NPs affected lipid metabolism and behaviour of the top consumer; they lose weight, the ratio and distribution of cholesterol to triglycerides in blood serum and at liver and muscle changed [182]. Shosaku Kashiwada used water-suspended fluorescent NPs to explore their distribution in the eggs and bodies of see-through medaka (ST II) (Oryzias latipes). Authors study ST II as a model because these animals have transparent embryos and body throughout its entire life, small size, tolerance toward wide salinity and temperature, short generation time and due to the fact that function of their tissues and organs are identical to those of mammals. ST II eggs exposed to fluorescent particles made of latex with a diameter of 39.4-42 $\mathrm{nm}$. Results of experiments showed that the mortality among the tested group was not observed. Fluorescence was found in whole eggs. In comparison with the yolk area, oil droplets and the egg envelope (chorion) showed higher fluorescence, however, no fluorescence was noticed in the spleen. Moreover, NPs were found in the blood, testis, liver, and brain of ST II. It was clearly shown that the concentration of NPs was 16.5 and $10.5 \mathrm{ng} / \mathrm{mg}$ in the blood of male and female respectively. The determinations of fluorescence in the brain tissue prove that NPs are able to pass the blood-brain barrier [210].

In conclusion, it should be noted that researches show that while nanoparticles involved in the food chain they can cause different changes in the organism of the top consumer. The main changes are observed in the metabolism and behaviour of tested organisms, such as slowly moving and swam closer. Moreover, the experiments reveal that NPs can cumulate in the liver, muscles, testis, blood, and brain of the test organisms. Due to the raised water content of brain texture at test top consumers, it becomes fluffy and nanoparticles mainly concentrated in the gills and intestine.

\subsubsection{Dendrimers}

Dendrimers are monodispersed synthetic particles with the range of $10-100 \mathrm{~nm}$ that are highly branched spherical polymer molecules with multivalent functional end groups $[212,213]$. Dendrimers are classified according to their sizes, chemical compositions and molecular weights depending on polymerization degree $[214,215]$. For the first time, the family of dendrimers was mentioned by D.A. Tomalia et al. in 1985 [209]. The term dendrimer was taken from the Greek words "Dendron" that means tree. There are two main approaches in the synthesis route of dendrimers: divergent synthesis (starting from the central core toward the periphery) and convergent synthesis (starting from the periphery toward the central core). Thanks to host-guest properties of dendrimers and their crucial properties like monodispersity, nano-size and shape, biocompatibility, periphery charge, dendrite membrane interaction and pharmacokinetics, they use a different type of drug delivery such as oral, ocular, transdermal, targeted drug delivery. Besides, in the medical field is applied dendrimers for cancer therapy. Dendrimers have been investigated as a carrier for numerous drugs such as anticancer, antiviral, antimalarial, antiprotozoal, anti-tubercular drugs and in gene delivery by means of introducing the external DNA into the cell. By tuning of dendrimers properties as 
a proper drug carrier system, it is possible to minimize the side effects and increase the therapeutic efficiency of actual drug [216-220].

Despite broad applicability in the medical field, the use of dendrimers in a biological system is constrained due to their toxicity. The observed toxicity of dendrimers in vivo experiments is explained by the interaction of their positively charged surface with negatively charged biological membranes. As a result, several processes such as membrane disruption via nanohole generation, membrane thinning and erosion occurred. Toxicities of dendrimers in the biological system commonly are defined by hemolytic toxicity, haematological toxicity and cytotoxicity. For keeping down the toxic effects two strategies have been used; masking of peripheral charge of dendrimers by surface engineering and synthesis and designing of biocompatible dendrimers [221]. Pryor J.B. et al. explored embryonic zebrafish (Danio rerio) as a model vertebrate for finding out the influence of dendrimer surface charge and generation on its toxicity. By decrease of the generation of polyamidoamine (PAMAM), dendrimers elicited significant morbidity and mortality in the tested group. The experiments show that at $120 \mathrm{hpf}$ embryos were assessed for mortality, behavioural and physical changes [222, 223]. A surface charge may be the best indicator of dendrimer toxicity, on the other hand, the dendrimer class and generation are also may be considered as the potential contributors to their toxicity. The results of the experiments indicate that thiophosphoryl dendrimers do not reveal the toxic effect. Despite this exposure of embryos to $\geq 50 \mathrm{ppm}$ cationic PAMAM dendrimers G3-amine, G4-amine, G5-amine, and G6-amine caused $100 \%$ mortality after $24 \mathrm{~h}$ fertilization. Neutral PAMAM G6-aminoethanol and anionic PAMAM G6-succinamic acid at $250 \mathrm{ppm}$ showed less toxic effect than the same concentration of Cationic PAMAM G6-amine [224]. Heiden T.C. et al. also used zebrafish as a rapid, costeffective whole-animal model to investigate the toxicity of PAMAM (G3.5 and G4). Results of experiments show that G4 (with terminal amino groups) reveal toxicity and affect growth and development of zebrafish embryos, causing their mortality. However, G3.5 dendrimers (with terminal carboxylic groups) are not toxic to zebrafish embryos. Furthermore, RGD-conjugated G3.5 dendrimers do not demonstrate toxicity tested at the highest concentrations and considered to be useful as a drug delivery device [225]. Kitchens K. M. et al. explored the potential of poly(amidoamine) (PAMAM) dendrimers as carriers for oral drug delivery and assumed that transepithelial transport and microvascular extravasation of PAMAM dendrimers are dependent on their structural features such as molecular size, molecular geometry, and surface chemistry. By optimizing these properties, it is possible to develop oral delivery systems based on these carriers for targeted drug delivery [226]. Dong Z. et al. used different generations (G0-G3) and concentrations [0.1-1.0\% (w/v)] of PAMAM dendrimers for investigation of pulmonary absorption of peptide and protein drugs at rats. In this research, the molecules of insulin and calcitonin were associated with dendrimers in order to reveal the ability of dendrimers as carriers of peptide and protein drugs. Consequently, they assumed that dendrimers significantly increased the pulmonary absorption of insulin and calcitonin without any membrane damage to the respiratory tissues in rats $(\mathrm{G} 3>\mathrm{G} 2>\mathrm{G} 1>\mathrm{G}$ ) $)$. The toxicity of PAMAM dendrimers in the lung tissues was estimated by measuring protein release and the activities of lactate dehydrogenase (LDH) in bronchoalveolar lavage fluid (BALF). The PAMAM dendrimers with various generations and concentrations did not significantly affect on the release of protein and the activities of LDH in BALF, and any membrane damage of the cells of lung tissues have not been observed [227].

According to some indications, it is supposed that dendrimers demonstrate cytotoxicity [221] observed at the cellular level due to the generational and charge effects. One of the possible reasons of the more pronounced cytotoxicity and hemolytic properties of cationic dendrimers comparing to anionic ones or PEGylated dendrimers [228] is that the cationic molecules, in general, can destabilize cell membranes, resulting in cell lysis [229]. But there is still a gap regarding successive systemized ecotoxicity studies of dendrimer NPs [230].

\subsubsection{Liposomes}

A liposome is a spherical vesicle with at least one lipid bilayer and formed by self-assembling while lipids molecules are exposed to an aqueous environment. Nanosized versions of liposomes called nanoliposomes [231, 232]. Liposomes have many applications nowadays; they used as pharmaceuticals for the treatment of cancer, bacterial, viral and parasitic diseases, and as cosmetic products. They also widely used in veterinary medicine, as immune adjuvants and vaccines $[233,234]$. Living cells membranes consist of the lipid bilayer and according to the structural similarity of the cell membrane with liposome wall, they have been investigated as models for drug delivery carriers. Liposomes particularly used in tissue engineering for promoting tissue regeneration at the human body [235]. The application of nanoliposomes as drug carrier is linked with critical issue concerning the liposomes design that is able to encapsulate the actual medicine, providing the proper release, which strongly influence on their therapeutic safety and efficacy until they reach the target site $[236,237]$. The experiments indicate that liposomes penetrate via cells membrane thanks to interactions with cell membrane components through electrostatic forces, or 
by means of non-specific weak hydrophobic forces [237]. Liposomes were widely and successfully used at cartilage repair in animal models [238]. Isabella Buttino et al. investigated the role of liposomes taken at the range of $30-80 \%$ of the total zooplankton biomass in marine areas in the diet of Copepods-the most widespread planktonic grazers in aquatic ecosystems [239]. Additionally, the Copepods represented the principal diet for fish larvaes [240]. It is well known that the quantity and quality of food plays an important role in the production rates and egg-hatching success, which are key biological parameters to predict secondary production at sea environment. The females of the Calanoid Copepod (Temora stylifera) were fed with fluorescein isothiocyanate-dextran (FitcDx) encapsulated liposomes and its mixture with the dinoflagellate alga Prorocentrum minimum ( $P$. minimum). At the same time, the control Copepods were incubated with the pristine P. minimum. Consequently, was found that when liposomes were conveying together with the algal diet, egg-hatching success, faecal pellet production, and egg production rate were as high as those observed for the control group. However, while using pure liposomes in diet, faecal pellet production was similar as with starved females, and egg production and hatching success were very low [241]. Barr Y. et al. investigated the enrichment of nutritional value of marine fish larviculture by feeding the live organisms by liposomes. The main goal of this study was to develop a simple method for mass-production of liposomes designed for the delivery of free amino acids (FAA) to filter-feeding zooplankton. After $2 \mathrm{~h}$ of live enrichment research shows that liposomes did not aggregate or disintegrate while suspending in water and the FAA content changes slightly-only $9 \%$ of the liposomes was lost after 2-h suspension [242].

Determining the fate of organic NPs in biological media, their biotransformation and removal from the body is definitely a very difficult task. The chemical structure of organic nanoparticles is often very similar to the chemical structure of many other biomolecules present in cells. It follows that the usual methods developed for organic substances can only be partially applied to the determination of organic NPs, and even more so to the determination of further transformations caused by their presence in the living organism.

\section{Conclusion}

In this article have been reviewed the data about the pathway of inorganic and organic NPs into the living organisms, their movement from one organism to another and the toxicity of NPs. It is known that NPs can be introduced into the environment through anthropogenic and natural routes; the natural NPs are considered to be non-toxic, whereas anthropogenic nanoparticles can reveal a toxic effect. Have been found that depending on the structure, size, surface charge, and concentration they are able to enter to organism directly-by external surface epithelia, by passage across gills, or indirectly-through inhalation system or digesting intake through the soil, water and feeding. In most cases, the toxicity of NPs reveals as changes in the level of reactive oxygen species, inflammation, neutron activation, cell, mRNA and DNA damage and etc. Introducing to the food chain the organic and inorganic NPs cause alterations on plants organs: leaves, flowers, stems, and roots and led to changes at the length of stem and root, chlorophyll content and at plant growth. The NPs impacts in animals mostly reveal as the changes occurring at the metabolic systems, behaviours and locomotive functions. The cumulations of NPs in the animals' organisms were observed at liver, kidney, lung, heart, gills and even in the brain tissues. Taking into consideration the collected numerous data regarding the engineering NPs effect towards the environment and living organisms and the gap of preventing measures towards their possible toxic impact there is a big demand of assessment of the risks, in order the better understanding the natural processes involving the NPs and development the safety protocols. The providing an effective assessment of the impact of NPs on the ecosystem and in particular on the food chain is based on the facts that the unique dimensional, surface and compositional properties of nanomaterials can vary their ability to interact with biological systems. It is necessary to generalize which aspects of their impact should be evaluated, nanomaterials features and their biologically significant characteristics for representative studies, that provide the development of reasonable approaches to impact assessment and as consequences can reduce risks of NPs toxicity.

\section{Compliance with ethical standards}

Conflict of interest On behalf of all authors, the corresponding author states that there is no conflict of interest.

\section{References}

1. Safari J, Zarnegar Z (2014) Advanced drug delivery systems: nanotechnology of health design a review. J Saudi Chem Soc. https://doi.org/10.1016/j.jscs.2012.12.009

2. Aitken RJ, Chaudhry MQ, Boxall ABA, Hull M (2006) Manufacture and use of nanomaterials: current status in the UK and global trends. Occup Med (Lond) 56(5):300-306

3. Jiang J, Oberdorster G, Biswas P (2008) Characterization of size, surface charge, and agglomeration state of nanoparticle dispersions for toxicological studies. J Nanopart Res 11:77-89 
4. Asati A, Santra S, Kaittanis C, Perez JM (2010) Surface-chargedependent cell localization and cytotoxicity of cerium oxide nanoparticles. ACS Nano 4(9):5321-5331

5. Frohlich E (2012) The role of surface charge in cellular uptake and cytotoxicity of medical nanoparticles. Int J Nanomed 7:5577-5591. https://doi.org/10.2147/IJN.S36111

6. Aslani F, Bagheri S, Julkapli NM, Juraimi AS, Hashemi FSG and Baghdadi A (2014) Effects of engineered nanomaterials on plants growth: an overview. Sci World J. http://dx.doi. org/10.1155/2014/641759

7. Shin SW, Song IH, Um SH (2015) Role of physicochemical properties in nanoparticle toxicity. Nanomaterials 5(3):13511365. https://doi.org/10.3390/nano5031351

8. Exbrayat J, Moudilou EN, Lapied E (2015) Harmful effects of nanoparticles on animals. J Nanotechnol. https://doi. org/10.1155/2015/861092

9. Matteo C, Candido P, Vera R, Francesca V (2012) Current and future nanotech applications in the oil industry. Am J Appl Sci 9(6):784-793

10. Wu J, He J, Torsæter O, Zhang Z (2012) Effect of nanoparticles on oil-water flow in a confined nanochannel: a molecular dynamics study. Soc Pet Eng J. https://doi.org/10.2118/15699 5-MS

11. Cheraghian $G$, Hendraningrat $L$ (2016) A review on applications of nanotechnology in the enhanced oil recovery part B: effects of nanoparticles on flooding. Int Nano Lett. https ://doi.org/10.1007/s40089-015-0173-4

12. De Jong WH, Borm Paul JA (2008) Drug delivery and nanoparticles: applications and hazards. Int J Nanomed 3(2):133-149

13. Reddy LH, Murthy RSR (2004) Pharmacokinetics and biodistribution studies of doxorubicin loaded poly (butyl cyanoacrylate) nanoparticles synthesized by two different techniques. Biomed Pap Med Fac Univ Palacky Olomouc Czech Repub 148(2):161-166

14. Maharramov AM, Ramazanov MA, Hasanova UA (2017) Nanostructures for antimicrobial therapy-the modern trends in the treatment of bacterial infections. Antimicrob Nanoarchitectonics. https://doi.org/10.1016/B978-0-323-52733 $-0.00016-1$

15. Mudshinge SR, Deore Amol B, Patil Sachin, Bhalgat Chetan M (2011) Nanoparticles: emerging carriers for drug delivery. Saudi Pharm J. https://doi.org/10.1016/j.jsps.2011.04.001

16. Qiu Y, Liu Y, Wang L, Xu L, Bai R, Ji Y, Wu X, Zhao Y, Li Y, Chen C (2010) Surface chemistry and aspect ratio mediated cellular uptake of Au nanorods. Biomaterials 31(30):7606-7619. https ://doi.org/10.1016/j.biomaterials.2010.06.051

17. Xia T, Kovochich $M$, Liong $M$, Meng $H$, Kabehie $S$, George $S$, Zink Jl, Nel AE (2009) Polyethy-leneimine coating enhances the cellular uptake of mesoporous silica nanoparticles and allows safe delivery of siRNA and DNA constructs. ACS Nano 3(10):3273-3286. https://doi.org/10.1021/nn900918w

18. Soenen $\mathrm{SJH}$, Himmelreich $U$, Nuytten $N$, Pisanic TR, Ferrari A, DeCuyper $M(2010)$ Intracellular nanoparticle coating stability determines nanoparticle diagnostics efficacy and cell functionality. Small 6(19):2136-2145. https://doi. org/10.1002/smll.201000763

19. Sahay G, Alakhova DY, Kabanov AV (2010) Endocytosis of nanomedicines. J Control Release 145(3):182-195. https:// doi.org/10.1016/j.jconrel.2010.01.036

20. Nuri Oh, Park Ji-Ho (2014) Endocytosis and exocytosis of nanoparticles in mammalian cells. Int J Nanomed 9(Suppl 1):51-63. https://doi.org/10.2147/IJN.S26592

21. Jiang J, Oberdorster G, Biswas P (2008) Characterization of size, surface charge, and agglomeration state of nanoparticle dispersions for toxicological studies. J Nanopart Res 11:77-89
22. Asati A, Santra S, Kaittanis C, Perez JM (2010) Surface-chargedependent cell localization and cytotoxicity of cerium oxide nanoparticles. ACS Nano 4(9):5321-5331

23. Frohlich E (2012) The role of surface charge in cellular uptake and cytotoxicity of medical nanoparticles. Int J Nanomed 7:5577-5591. https://doi.org/10.2147/IJN.S36111

24. Schaeublin NM, Braydich-Stolle LK, Schrand AM, Miller JM, Hutchison J, Schlager JJ, Hussain SM (2011) Surface charge of gold nanoparticles mediates mechanism of toxicity. Nanoscale 3(2):410-420. https://doi.org/10.1039/c0nr00478b

25. Hussain SM, Hess KL, Gearhart JM, Geiss KT, Schlager JJ (2005) In vitro toxicity of nanoparticles in BRL3A rat liver cells. Toxicol In Vitro 19(7):975-983. https://doi.org/10.1016/j.tiv.2005.06.034

26. Agarwal M, Murugan MS, Sharma A, Rai R, Kamboj A, Sanjeev HS, Roy K (2013) Nanoparticles and its toxic effects: a review. Int J Curr Microbiol App Sci 2(10):76-82

27. Hund-Rinke Kerstun, Simon Markus (2006) Ecotoxic effect of photocatalytic active nanoparticles (Ti2O) on algae and daphinds. Environ Sci Pollut Res 13:225-232

28. Gilro KD, Neretina S, Sanders RW (2014) Behavior of gold nanoparticles in an experimental algal-zooplankton food chain. J Nanopart Res 16:2414. https://doi.org/10.1007/s1105 1-014-2414-2

29. Moller P, Jacobsen NR, Folkmann JK, Danielsen PH, Mikkelsen $L$ (2010) Role of oxidative damage in toxicity of particulates. Free Radic Res 44(1):1-46. https://doi.org/10.3109/1071576090 3300691

30. Madl AK, Plummer LE, Carosino C, Pinkerton KE (2014) Nanoparticles, lung injury, and the role of oxidant stress. Annu Rev Physiol 76:447-465. https://doi.org/10.1146/annurev-physi ol-030212-183735

31. Jaurand MF, Renier A, Daubriac J (2009) Mesothelioma: do asbestos and carbon nanotubes pose the same health risk. Part Fibre Toxicol 6:16. https://doi.org/10.1186/1743-8977-6-16

32. Panariti A, Miserocchi G, Rivolta I (2012) The effect of nanoparticle uptake on cellular behavior: disrupting or enabling functions? Nanotechnol Sci Appl 5:87-100. https://doi.org/10.2147/ NSA.S25515

33. Shang L, Nienhaus K, Nienhaus GU (2014) Engineered nanoparticles interacting with cells: size matters. J Nanobiotechnol 12:5. https://doi.org/10.1186/1477-3155-12-5

34. Kettiger H, Schipanski A, Wick P, Huwyler J (2013) Engineered nanomaterial uptake and tissue distribution: from cell to organism. Int J Nanomed 2013(8):3255-3269

35. Manke A, Wang L, Rojanasakul Y (2013) Mechanisms of nanoparticle-induced oxidative stress and toxicity. Biomed Res Int. https://doi.org/10.1155/2013/942916

36. Rao CN, Ramakrishna Matte HS, Voggu R, Govindaraj A (2012) Recent progress in the synthesis of inorganic nanoparticles. Dalton Trans 41:5089-5120. https://doi.org/10.1039/C2DT1 2266A

37. Yang Z, Chen J, Dou R, Gao X, Mao C, Wang L (2015) Assessment of the phytotoxicity of metal oxide nanoparticles on two crop plants, maize (Zea mays L.) and rice (Oryza sativa L.). Int J Environ Res Public Health 12(12):15100-15109. https://doi. org/10.3390/ijerph121214963

38. Bakunin VN, Suslov YA, Kuzmina GN, Parenago OP, Topchiev AV (2004) Synthesis and application of inorganic nanoparticles as lubricant components. J Nanopart Res 6:273-284

39. Casals $\mathrm{E}$, Bastus $\mathrm{N}$, Vázquez $\mathrm{S}$, Varon $\mathrm{M}$, Comenge J, Puntes V (2008) Inorganic nanoparticles and biology. Contrib Sci 4(2):171-176. https://doi.org/10.2436/20.7010.01.47

40. Oberdorster G, Oberdorster E, Oberdorster J (2005) Nanotoxicology: an emerging discipline evolving from studies of ultrafine particles. Environ Health Perspect 113(7):823-839 
41. Mody VV, Siwale R, Singh A, Mody HR (2010) Introduction to metallic nanoparticles. J Pharm Bioallied Sci 2(4):282-289. https://doi.org/10.4103/0975-7406.72127

42. Farkas J, Christian P, Urrea JA, Roos N, Hassellöv M, Tollefsen KE, Thomas KV (2010) Effects of silver and gold nanoparticles on rainbow trout (Oncorhynchus mykiss) hepatocytes. Aquat Toxicol 96(1):44-52. https://doi.org/10.1016/j.aquatox.2009.09.016

43. Buzea C, Pacheco II, Robbie K (2007) Nanomaterials and nanoparticles: sources and toxicity. Biointerphases 2(4):MR17-MR71

44. Jakubiak M, Giska I, Asztemborska M, Bystrzejewska-Piotrowska $\mathrm{G}$ (2014) Bioaccumulation and biosorption of inorganic nanoparticles: factors affecting the efficiency of nanoparticle my co extraction by liquid-grown mycelia of Pleurotus eryngii and Trametes versicolor. Mycol Progress 13:525-532

45. Majumdar S, Trujillo-Reyes J, Hernandez-Viezcas JA, White JC, Peralta-Videa JR, Gardea-Torresdey JL (2015) Cerium biomagnification in a terrestrial food chain: influence of particle size and growth stage. Environ Sci Technol 50(13):6782-6792. https ://doi.org/10.1021/acs.est.5b04784

46. Farooq W, Lee HU, Huh YS, Lee Y (2016) Chlorella vulgaris cultivation with an additive of magnesium-aminoclay. Algal Res. https://doi.org/10.1016/j.algal.2016.05.004

47. Meredith GC, Lilianne MA, Karen AK, Nelson JO, Mark LM (2014) Mercury bioaccumulation and biomagnification in a small Arctic polynya ecosystem. Sci Total Environ 509:206-215

48. Bondarenko $O$, Juganson $K$, Ivask $A$, Kasemets $K$, Mortimer $M$, Kahru A (2013) Toxicity of Ag, CuO and ZnO nanoparticles to selected environmentally relevant test organisms and mammalian cells in vitro: a critical review. Arch Toxicol 87(7):1181-1200. https://doi.org/10.1007/s00204-013-1079-4

49. Wang T, Chen X, Long X, Liu Z, Yan S (2016) Copper nanoparticles and copper sulphate induced cytotoxicity in hepatocyte primary cultures of epinephelus coioides. PLoS ONE 11(2):e0149484. https://doi.org/10.1371/journal.pone.0149484

50. Kwak Jl, Lee WM, Kim SW, An YJ (2014) Interaction of citratecoated silver nanoparticles with earthworm coelomic fluid and related cytotoxicity in Eisenia Andrei. J Appl Toxicol 34(11):1145-1154. https://doi.org/10.1002/jat.2993

51. Oukarroum A, Bras S, Perreault F, Popovic R (2012) Inhibitory effects of silver nanoparticles in two green algae, Chlorella vulgaris and Dunaliella tertiolecta. Ecotoxicol Environ Saf 78:80-85. https://doi.org/10.1016/j.ecoenv.2011.11.012

52. Guénette S, Meissa B, Gascuel D (2014) Assessing the contribution of marine protected areas to the trophic functioning of ecosystems: a model for the banc d'arguin and the mauritanian shelf. PLoS ONE 2014:1-16

53. Zhu X, Wang J, Zhang X, Chang Y, Chen Y (2010) Trophic transfer of TiO2 nanoparticles from Daphnia to zebrafish in a simplified fresh water food chain. Chemosphere 79:928-933

54. Uboldi C, Urbán P, Gilliland D, Bajak E, Valsami-Jones E, Ponti J, Rossi F (2016) Role of the crystalline form of titanium dioxide nanoparticles: rutile and not anatase, induces toxic effects in Balb/3T3 mouse fibroblasts. Toxicol In Vitro 31:137-145. https ://doi.org/10.1016/j.tiv.2015.11.005

55. Kubo-Irie M, Yokoyama M, Shinkai Y, Niki R, Takeda K, Irie M (2016) The transfer of titanium dioxide nanoparticles from the host plant to butterfly larvae through a food chain. Sci Rep 6:23819. https://doi.org/10.1038/srep23819

56. Jovanović B, Whitley EM, Kimura K, Crumpton A, Boris PD (2015) Titanium dioxide nanoparticles enhance mortality of fish exposed to bacterial pathogens. Environ Pollut 203:153-164. https://doi.org/10.1016/j.envpol.2015.04.003

57. McClements DJ, Xiao H (2017) Is nano safe in foods? Establishing the factors impacting the gastrointestinal fate and toxicity of organic and inorganic food-grade nanoparticles. NPJ Sci Food 1:6. https://doi.org/10.1038/s41538-017-0005-1
58. Amara S, Younes NR, Mrad I, Ben-Slama I, Jeljeli M, Omri K, El Ghoul J, El Mir L, Rhouma KB, Abdelmelek H, Sakly M (2014) Subacute toxicity of titanium dioxide (TiO2) nanoparticles in male rats: emotional behavior and pathophysiological examination. Environ Sci Pollut Res 22(11):8728-8737. https://doi. org/10.1007/s11356-014-4002-5

59. Ge S, Wang G, Shen Y, Zhang Q, Jia D, Wang H, Dong Q, Yin $\mathrm{T}$ (2011) Cytotoxic effects of MgO nanoparticles on human umbilical vein endothelial cells in vitro. IET Nanobiotechnol 5(2):36. https://doi.org/10.1049/iet-nbt.2010.0022

60. Alshatwi AA, Periasamy VS, Athinarayanan J (2014) Cytotoxic effects of engineered nanoparticles in human mesenchymal stem cells. Int J Sci Eng Innov Res 8(9):596-599

61. Mahmoud A, Ezgi O, Merve A, Ozhan G (2016) In vitro toxicological assessment of magnesium oxide nanoparticle exposure in several mammalian cell types. Int J Toxicol 35(4):429-437. https://doi.org/10.1177/1091581816648624

62. Ali D, Ali H, Alarifi S, Masih AP, Manohardas S, Hussain SA (2016) Genotoxicity in the freshwater gastropod Lymnaea luteola L: assessment of cell type sensitivities to lead nitrate. Fresenius Environ Bull. https://doi.org/10.1080/02757540.2016.1275587

63. Ghobadian M, Nabiuni M, Parivar K, Fathi M, Pazooki J (2015) The toxic effects of magnesium oxide nanoparticles on early developmental and larval stages of zebrafish (Danio rerio). Ecotoxicol Environ Saf 122:260-267. https://doi.org/10.1016/j. ecoenv.2015.08.009

64. Hasanein P, Parviz M, Keshavarz M, Javanmardi K, Allahtavakoli M, Ghaseminejad M (2007) Modulation of cholestasis-induced antinociception in rats by two NMDA receptor antagonists: MK801 and magnesium sulfate. Eur J Pharmacol 554(2-3):123127. https://doi.org/10.1016/j.ejphar.2006.10.026

65. Gerstein M, Huleihel M, Mane R, Stilman M, Kashtuzki I, Hallak M, Golan H (2005) Remodeling of hippocampal GABAergic system in adult offspring after maternal hypoxia and magnesium sulfate load: immunohistochemical study. Exp Neurol. https:// doi.org/10.1016/j.expneurol.2005.06.019

66. Poleszak E (2008) Benzodiazepine/GABA (A) receptors are involved in magnesium-induced anxiolytic-like behavior in mice. Pharmacol Rep 60(4):483-489

67. Kesmati M, Torabi M, Zamaneh HT, Nia HM (2014) Interaction between anxiolytic effects of magnesium oxide nanoparticles and exercise in adult male rat. Nanomed $\mathrm{J}$ 1:324-330

68. Jahangiri L, Kesmati M, Najafzadeh H (2014) Effect of magnesium oxide nanoparticles in comparison with conventional $\mathrm{MgO}$ in diabetic and non-diabetic male mice. Basic Clin Neurosci 5(2):156-161

69. Choopun S, Tubtimtae A, Santhaveesuk T, Nilphai S, Wongrat E, Hongsith N (2009) Zinc oxide nanostructures for applications as ethanol sensors and dye-sensitized solar cells. Appl Surf Sci. https://doi.org/10.1016/j.apsusc.2009.05.139

70. Hanna SK, Miller RJ, Muller EB, Nisbet RM, Lenihan HS (2013) Impact of engineered zinc oxide nanoparticles on the individual performance of mytilusgalloprovincialis. PLOS ONE. https ://doi.org/10.1371/journal.pone.0061800

71. Srivastava V, Gusain D, Sharma YC (2013) Synthesis, characterization and application of zinc oxide nanoparticles ( $\mathrm{n}-\mathrm{ZnO})$. Ceram Int. https://doi.org/10.1016/j.ceramint.2013.04.110

72. Kumar P, Walia YK (2014) Synthesis and Structural properties of zinc oxide nano particles (ZnO NPs): a review. Asian J Adv Basic Sci 2(3):39-49

73. Yoon SJ, Kwak JI, Lee WM, Holden PA, An YJ (2013) Zinc oxide nanoparticles delay soybean development: a standard soil microcosm study. Ecotoxicol Environ Saf 100:131-137. https ://doi.org/10.1016/j.ecoenv.2013.10.014

74. Manzo S, Rocco A, Carotenuto R, Picione FL, Miglietta ML, Rametta G, Di Francia G (2011) Investigation of ZnO 
nanoparticles' ecotoxicological effects towards different soil organisms. Environ Sci Pollut Res 18(5):756-763. https://doi. org/10.1007/s11356-010-0421-0

75. Choi JS, Kim RO, Yoon S, Kim WK (2016) Developmental toxicity of zinc oxide nanoparticles to zebrafish (Danio rerio): a transcriptomic analysis. PLoS ONE. https://doi.org/10.1371/ journal.pone.0160763

76. Hong R, Pan T, Qian J, Li H (2006) Synthesis and surface modification of $\mathrm{ZnO}$ nanoparticles. Chem Eng J. https://doi. org/10.1016/j.cej.2006.03.003

77. Corredor E, Testillano PS, Coronado MJ, González-Melendi P, Fernández-Pacheco R, Marquina $C$, Ibarra MR, de la Fuente JM, Rubiales D, Pérez-de-Luque A, Risueño MC (2009) Nanoparticle penetration and transport in living pumpkin plants: in situ subcellular identification. BMC Plant Biol 9:45. https ://doi.org/10.1186/1471-2229-9-45

78. Ito A, Shinkai M, Honda H, Kobayashi T (2005) Medical application of functionalized magnetic nanoparticles. J Biosci Bioeng. https://doi.org/10.1263/jbb.100.1

79. Mody VV, Cox A, Shah S, Singh A, Bevins W, Parihar H (2013) Magnetic nanoparticle drug delivery systems for targeting tumor. Appl Nanosci 4:385-392

80. Chockalingam AM, Babu HK, Chittor R, Tiwari JP (2010) Gum arabic modified $\mathrm{Fe} 3 \mathrm{O} 4$ nanoparticles cross linked with collagen for isolation of bacteria. J Nanobiotechnol. https://doi. org/10.1186/1477-3155-8-30

81. Jun YW, Huh YM, Choi JS, Lee JH, Song HT, Kim S, Yoon S, Kim KS, Shin JS, Suh JS, Cheon J (2005) Nanoscale size effect of magnetic nanocrystals and their utilization for cancer diagnosis via magnetic resonance imaging. J Am Chem Soc 127(16):5732-5733. https://doi.org/10.1021/ja0422155

82. Wang X, Summers CJ, Wang ZL (2004) Large scale hexagonal patterned growth of aligned $\mathrm{ZnO}$ nanorods for nanooptoelectronics and nanosensor arrays. Nano Lett 4(3):423-426. https://doi.org/10.1021/nl035102c

83. Gupta AK, Gupta M (2004) Synthesis and surface engineering of iron oxide nanoparticles for biomedical applications. Biomaterials 26(18):3995-4021. https://doi.org/10.1016/j.bioma terials.2004.10.012

84. Gao J, Gu H, Xu B (2009) Multifunctional magnetic nanoparticles: design, synthesis and biomedical applications. Acc Chem Res 42(8):1097-1107. https://doi.org/10.1021/ar900 0026

85. Perez JM, Simeone FJ, Saeki Y, Josephson L, Weissleder R (2003) Viral-induced self-assembly of magnetic nanoparticles allows the detection of viral particles in biological media. J Am Chem Soc 125(34):10192-10193. https://doi.org/10.1021/ja036409g

86. Shabanov AL, Ramazanova EM, Hasanova UA (2013) Method of preparing a nanoparticulate iron-crown ether complex. US 8,420, 837 B2

87. Shabanov AL, Ramazanova EM, Hasanova UA (2014) Methods for reducing heavy oil viscosity. US 2014/0345192 Al

88. Piccinetti CC, Montis C, Bonini M, Laurà R, Guerrera MC, Radaelli G, Vianello F, Santinelli V, Maradonna F, Nozzi V, Miccoli A, Olivotto I (2014) Transfer of silica-coated magnetic (Fe3O4) nanoparticles through food: a molecular and morphological study in zebrafish. Zebrafish 11(6):567-579. https://doi. org/10.1089/zeb.2014.1037

89. Zhu H, Han J, Xiao JQ, Jin Y (2008) Uptake, translocation, and accumulation of manufactured iron oxide nanoparticles by pumpkin plants. J Environ Monit 10(6):713-717. https://doi. org/10.1039/b805998e

90. Maharramov AM, Ramazanov MA, Hajili RA, Hasanova UA, Hajiyeva SF, Eyvazova GM, Hajiyeva FV, Huseynzade AE, Hajili NM (2016) The synthesis and coupling with magnetite nanoparticles of 4,6-dimethyl-2-(2-Oxyethyl)- 1,2-dihydro-3 h-pyrrolo
[3,4-C] pyridine-3-one and characterization its structure. JOBM 8:169-174

91. Hasanova UA, Ramazanov MA, Maharramov AM, Gakhramanova Z, Hajiyeva SF, Eyvazova QM, Vezirova L, Hajiyeva FV, Hasanova M, Guliyeva N (2016) Synthesis of macrocycle (MC) mimics the properties of natural siderophores and preparation the nanostructures on the basis of MC and magnetite nanoparticles. Chem Eng Trans 47:109-114. https://doi.org/10.3303/ CET1647019

92. Hasanova UA, Ramazanov MA, Maharramov AM, Gakhramanova Z, Hajiyeva SF, Vezirova L, Eyvazova GM, Hajiyeva FV, Huseynova P, Agamaliyev ZA (2016) The functionalization of magnetite nanoparticles by hydroxyl substituted diazacrown ether, able to mimic natural siderophores, and investigation of their antimicrobial activity. J Incl Phenom Macrocycl Chem 86:19-25

93. Hasanova UA, Ramazanov MA, Maharramov AM, Eyvazova QM, Agamaliyev ZA, Parfyonova YV, Hajiyeva SF, Hajiyeva FV, Veliyeva SB (2015) Nano-coupling of cephalosporin antibiotics with $\mathrm{Fe} 3 \mathrm{O} 4$ nanoparticles: trojan horse approach in antimicrobial chemotherapy of infections caused by Klebsiella. spp. J Biomater Nanobiotechnol 6:225-235. https://doi.org/10.4236/ jbnb.2015.63021

94. Maharramov AM, Ahmadov IS, Ramazanov MA, Aliyeva SQ, Ramazanli VN (2015) Fluorescence emission spectrum of elodea leaves exposed to nanoparticles. J Biomater Nanobiotechnol. https://doi.org/10.4236/jbnb.2015.63013

95. Ahmadov IS, Ramazanov MA, Sienkıewıcz A, Forro L (2014) Uptake and intracellular trafficking of superparamagnetic iron oxide nanoparticles (spions) in plants. Dig J Nanomater Biostruct 9(3):1149-1157

96. Bombin S, LeFebvre M, Sherwood J, Xu Y, Bao Y, Ramonell KM (2015) Developmental and reproductive effects of iron oxide nanoparticles in Arabidopsis thaliana. Int J Mol Sci 16(10):24174-24193. https://doi.org/10.3390/ijms161024174

97. Jain TK, Reddy MK, Morales MA, Leslie-Pelecky DL, Labhasetwar V (2008) Biodistribution, clearance, and biocompatibility of iron oxide magnetic nanoparticles in rats. Mol Pharm 5(2):316-327. https://doi.org/10.1021/mp7001285

98. Li J, Hu J, Ma C, Wang Y, Wu C, Huang J, Xing B (2016) Uptake, translocation and physiological effects of magnetic iron oxide (g-Fe2O3) nanoparticles in corn (Zea mays L.), Chemosphere. https://doi.org/10.1016/j.chemosphere.2016.05.083

99. Di Bona KR, Xu Y, Ramirez PA, DeLaine J, Parker C, Bao Y, Rasco JF (2014) Surface charge and dosage dependent potential developmental toxicity and biodistribution of iron oxide nanoparticles in pregnant CD-1 mice. Reprod Toxicol 50:36-42. https:// doi.org/10.1016/j.reprotox.2014.09.010

100. Ghosh P, Han G, De M, Kim CK, Rotello VM (2008) Gold nanoparticles in delivery applications. Adv Drug Deliv Rev. https:// doi.org/10.1016/j.addr.2008.03.016

101. Raghavendra R, Arunachalam K, Annamalai SK, Arunachalam AM (2014) Diagnostics and therapeutic application of gold nanoparticles. Int J Pharm Pharm Sci 6(2):74-87

102. Sperling RA, Gil PR, Zhang F, Zanella M and Parak WJ (2008) Biological applications of gold nanoparticles. Chem Soc Rev. https://doi.org/10.1039/b712170a

103. Das M, Shim KH, Seong Soo AA, Yi DK (2011) Review on gold nanoparticles and their applications. Toxicol Environ Health Sci 3:193-205

104. Judy JD, Unrine JM, Bertsch PM (2011) Evidence for biomagnification of gold nanoparticles within a terrestrial food chain. Environ Sci Technol 2:776-781. https://doi.org/10.1021/es103 031a

105. Cho EC, Xie J, Wurm PA, Xia Y (2009) Understanding the role of surface charges in cellular adsorption versus internalization 
by selectively removing gold nanoparticles on the cell surface with a I2/KI etchant. Nano Lett 9(3):1080-1084. https://doi. org $/ 10.1021 / \mathrm{nl} 803487 \mathrm{r}$

106. Bozich JS, Lohse SE, Torelli MD, Murphy CJ, Hamers RJ, Klaper RD (2014) Surface chemistry, charge and ligand type impact the toxicity of gold nanoparticles to Daphnia magna. Environ Sci Nano 1:260-270

107. Chen H, Dorrigan A, Saad S, Hare DJ, Cortie MB, Valenzuela SM (2013) In vivo study of spherical gold nanoparticles: inflammatory effects and distribution in mice. PLoS ONE. https://doi. org/10.1371/journal.pone.0058208

108. Unrine JM, Aaron Shoults-Wilson W, Zhurbich O, Bertsch PM, Tsyusko OV (2012) Trophic transfer of Au nanoparticles from soil along a simulated terrestrial food chain. Environ Sci Technol 46(17):9753-9760. https://doi.org/10.1021/es3025325

109. Cassee FR, van Balen EC, Singh C, Green D, Muijser H, Weinstein J, Dreher K (2011) Exposure, health and ecological effects review of engineered nanoscale cerium and cerium oxide associated with its use as a fuel additive. Crit Rev Toxicol 41(3):213229. https://doi.org/10.3109/10408444.2010.529105

110. Xu C, Qu X (2014) Cerium oxide nanoparticle: a remarkably versatile rare earth nanomaterial for biological applications. NPG Asia Mater 6:90. https://doi.org/10.1038/am.2013.88

111. Clément L, Hurel C, Marmier N (2013) Toxicity of TiO2 nanoparticles to cladocerans, algae, rotifers and plants-effects of size and crystalline structure. Chemosphere. https://doi. org/10.1016/j.chemosphere.2012.09.013

112. White JC, Hawthorne J, De La T Roche R, Xing B, Newman LA, Ma X, Majumdar S, Gardea-Torresdey JL (2014) Particlesize dependent accumulation and trophic transfer of cerium oxide through a terrestrial food chain. Environ Sci Technol 48(22):13102-13109. https://doi.org/10.1021/es503792f

113. Ahamed M, Akhtar MJ, Alhadlaq HA, Alrokayan SA (2015) Assessment of the lung toxicity of copper oxide nanoparticles: current status. Nanomed (Lond) 10(15):2365-2377

114. Gui X, Zhang Z, Liu S, Ma Y, Zhang P, He X et al (2015) Fate and phytotoxicity of $\mathrm{CeO} 2$ nanoparticles on lettuce cultured in the potting soil environment. PLoS ONE 10(8):e0134261. https:// doi.org/10.1371/journal.pone.013426

115. Chen Y, Sanchez C, Yue Y, de Almeida M, González JM, Parkinson DY, Liang H (2016) Observation of yttrium oxide nanoparticles in cabbage (Brassica oleracea) through dual energy K-edge subtraction imaging. J Nanobiotechnol 14:23. https://doi. org/10.1186/s12951-016-0175-z

116. Ramazanov MA, Ahmadov IS, Ramazanli VN, Agayeva NJ (2015) Effect of nanoparticles on the activity of the electron ion pumps in plasmatic membrane of plant cells. Trends Nanotechnol Mater Sci 1:1-5

117. Gupta YR, Sellegounder D, Kannan M, Deepa S, Senthilkumaran B, Basavaraju Y (2016) Effect of copper nanoparticles exposure in the physiology of the common carp (Cyprinus carpio): biochemical, histological and proteomic approaches. Aqualt Fish. https://doi.org/10.1016/j.aaf.2016.09.003

118. Villarreal FD, Das GK, Abid A, Kenned IM, Kültz D (2014) Sublethal effects of CuO nanoparticles on Mozambique Tilapia (Oreochromis mossambicus) are modulated by environmental salinity. PLoS ONE. https://doi.org/10.1371/journal.pone.00887 23

119. Nations S, Long M, Wages M, Maul JD, Theodorakis CW, Cobb GP (2015) Subchronic and chronic developmental effects of copper oxide $(\mathrm{CuO})$ nanoparticles on Xenopus laevis. Chemosphere 135:166-174. https://doi.org/10.1016/j.chemospher e.2015.03.078

120. Song G, Hou W, Gao Y, Wang Y, Lin L, Zhang Z, Niu Q, Ma R, Mu $\mathrm{L}$, Wang $\mathrm{H}$ (2016) Effects of CuO nanoparticles on lemna minor. Bot Stud 57(1):3. https://doi.org/10.1186/s40529-016-0118-x
121. Ogunkunle CO, Bornmann B, Wagner R, Luetzenkirchen-Hecht $D$. Biotransformation evidence of copper nanoparticles in cowpea (Vigna unguiculata) by XANES, Research. https://doi. org/10.13140/rg.2.2.11579.62249

122. Singh J, Kaur G, Rawat MA (2016) Brief review on synthesis and characterization of copper oxide nanoparticles and its applications. J Bioelectron Nanotechnol. https://doi.org/10.13188 /2475-224X.1000003

123. Chang Y, Zhang M, Xia L, Zhang J, Xing G (2012) The toxic effects and mechanisms of $\mathrm{CuO}$ and $\mathrm{ZnO}$ nanoparticles. Materials 5(12):2850-2871. https://doi.org/10.3390/ma5122850

124. Rauwel P, Rauwel E, Ferdov S, and Singh MP (2015) Silver Nanoparticles: Synthesis, Properties, and Applications. Adv Mater Sci Eng. http://dx.doi.org/10.1155/2015/624394

125. Martínez-Gutierrez F, Thi EP, Silverman JM, de Oliveira CC, Svensson SL, Vanden Hoek A, Sánchez EM, Reiner NE, Gaynor EC, Pryzdial EL, Conway EM, Orrantia E, Ruiz F, Av-Gay Y, Bach H (2012) Antibacterial activity, inflammatory response, coagulation and cytotoxicity effects of silver nanoparticles. Nanomedicine 8(3):328-336. https://doi.org/10.1016/j.nano.2011.06.014

126. Ramazanov MA, Maharramov AM, Nuriyeva SQ, Hasanova UA, Hajiyeva FV (2016) Preparation and study of nanocomposite structures based on polypropylene and silver sulphide. Chalcogenide Lett 13:317-324

127. Jannathul Firdhouse $M$, Lalitha $P$ (2015) Biosynthesis of silver nanoparticles and its applications. J Nanotechnol. https://doi. org/10.1155/2015/829526

128. Prabhu S, Poulose EK (2012) Silver nanoparticles: mechanism of antimicrobial action, synthesis, medical applications, and toxicity effects. Int Nano Lett 2:32

129. Tran QH, Nguyen VQ, Le A (2013) Silver nanoparticles: synthesis, properties, toxicology, applications and perspectives. Adv Nat Sci Nanosci Nanotechnol 4:1-20. https://doi.org/10.1088/20436262/4/3/033001

130. Kholoud MM, El-Nour A, Eftaiha A, AI-Warthan A, Ammar RAA (2010) Synthesis and applications of silver nanoparticles. Arab J Chem 3:135-140. https://doi.org/10.1016/j.arabjc.2010.04.008

131. Ganbarov KhG, Ahmadov IS, Ramazanov MA, Musayev EM, Eyvazova QI, Aghamaliyev ZA (2014) Silver nanoparticles synthesized by the azerbaijanian environmental isolates Aspergillus niger. J Microbiol Biotech Food Sci 4(2):137-141. https://doi. org/10.15414/jmbfs.2014.4.2.137-141

132. Asztemborska $M$, Jakubiak $M$, Książyk $M$, Stęborowski $R$, Polkowska-Motrenko H, Bystrzejewska-Piotrowska G (2014) Silver nanoparticle accumulation by aquatic organisms - neutron activation as a tool for the environmental fate of nanoparticles tracing. Nukleonika 59(4):169-173. https://doi.org/10.2478/ nuka-2014-0023

133. Chae YJ, Pham CH, Lee J, Bae E, Yi J, Gu MB (2009) Evaluation of the toxic impact of silver nanoparticles on Japanese medaka (Oryzias latipes). Aquat Toxicol 94(4):320-327. https://doi. org/10.1016/j.aquatox.2009.07.019

134. Wu Y, Zhou Q (2013) Silver nanoparticles cause oxidative damage and histological changes in medaka (Oryziaslatıpes) after 14 days of exposure. Environ Toxicol Chem 32(1):165-173. https ://doi.org/10.1002/etc.2038

135. Kwak Jl, An YJ (2016) Trophic transfer of silver nanoparticles from earthworms disrupts the locomotion of springtails (Collembola). J Hazard Mater 315:110-116. https://doi. org/10.1016/j.jhazmat.2016.05.005

136. Bharti C, Nagaich U, Pal AK, Gulati N (2015) Mesoporous silica nanoparticles in target drug delivery system: a review. Int J Pharm Investig 5(3):124-133. https://doi.org/10.4103/2230973X.160844

137. Rahman IA, Padavettan V (2012) Synthesis of silica nanoparticles by Sol-Gel: size-dependent properties, 
surface modication, and applications in silica-polymer nanocomposites - a review. J Nanomater. https://doi. org/10.1155/2012/132424

138. Wu S, Mou C, Lin H (2013) Synthesis of mesoporous silica nanoparticles. Chem Soc Rev 42:3862-3875. https://doi. org/10.1039/C3CS35405A

139. Hofmann T, Schneider S, Wolterbeek A, van de Sandt H, Landsiedel R, van Ravenzwaay B (2015) Prenatal toxicity of synthetic amorphous silica nanomaterial in rats. Reprod Toxicol 56:141146. https://doi.org/10.1016/j.reprotox.2015.04.006

140. Fent K, Weisbrod CJ, Wirth-Heller A, Pieles U (2010) Assessment of uptake and toxicity of uorescent silica nanoparticles in zebrash (Danio rerio) early life stages. Aquat Toxicol 100(2):218228. https://doi.org/10.1016/j.aquatox.2010.02.019

141. Ambrosone A, Scotto di Vettimo MR, Malvindi MA, Roopin M, Levy O, Marchesano V, Pompa PP, Tortiglione C, Tino A (2014) Impact of amorphous $\mathrm{SiO} 2$ nanoparticles on a living organism: morphological, behavioral, and molecular biology implications. Front Bioeng Biotechnol 2:37. https://doi.org/10.3389/fbioe .2014 .00037

142. Wei C, Zhang Y, Guo J, Han B, Yang X, Yuan J (2010) Effects of silica nanoparticles on growth and photosynthetic pigment contents of Scenedesmus obliquus. J Environ Sci 22:155-160. https://doi.org/10.1016/S1001-0742(09)60087-5

143. Priya KK, Ramesh M, Saravanan M, Ponpandian N (2015) Ecological risk assessment of silicon dioxide nanoparticles in a freshwater fish Labeo rohita: hematology, ionoregulation and gill Nap/Kp ATPase activity. Ecotoxicol Environ Saf 120:295-302. https://doi.org/10.1016/j.ecoenv.2015.05.032

144. Uritu CM, Varganici CD, Ursu L, Coroaba A, Nicolescu A, Dascalu Al, Peptanariu D, Stan D, Constantinescu CA, Simion V, Calin M, Maier SS, Pinteala M, Barboiu M (2015) Hybrid fullerene conjugates as vectors for DNA cell-delivery. J Mater Chem B 3:2433-2446. https://doi.org/10.1039/C4TB02040E

145. Peddini SK, Bosnyak CP, Henderson NM, Ellison CJ, Paul DR (2014) Nanocomposites from styrene-butadiene rubber (SBR) and multiwall carbon nanotubes (MWCNT) part 1: morphology and rheology. Polymer 55:258-270. https://doi.org/10.1016/j. polymer.2013.11.003

146. Gohardani O, Elola M C, Elizetxea C (2014) Potential and prospective implementation of carbon nanotubes on next generation aircraft and space vehicles: a review of current and expected applications in aerospace sciences. Prog Aerosp Sci. https://doi.org/10.1016/j.paerosci.2014.05.002

147. Kato S, Taira H, Aoshima H, Saitoh Y, Miwa N (2010) Clinical evaluation of fullerene-C (60) dissolved in squalane for antiwrinkle cosmetics. J Nanosci Nanotechnol 10(10):6769-6774

148. De Volder MF, Tawfick SH, Baughman RH, Hart AJ (2013) Carbon nanotubes: present and future commercial applications. Science 339(6119):535-539. https://doi.org/10.1126/scien ce.1222453

149. Zhang W, Zhang Z, Zhang Y (2011) The application of carbon nanotubes in target drug delivery systems for cancer therapies. Nanoscale Res Lett 6:555. https://doi. org/10.1186/1556-276X-6-555

150. Zaytseva O, Neumann G (2016) Carbon nanomaterials: production, impact on plant development, agricultural and environmental applications. Chem Biol Technol Agric 3:17. https://doi. org/10.1186/s40538-016-0070-8

151. Jackson $P$, Jacobsen NR, Baun $A$, Birkedal $R$, Kühnel $D$, Jensen KA, Vogel U, Wallin H (2013) Bioaccumulation and ecotoxicity of carbon nanotubes. Chem Cent J 7:154. https://doi. org/10.1186/1752-153X-7-154

152. Choi W, Lahiri I, Seelaboyina R, and Kang YS (2010) Synthesis of graphene and its applications: a review. Crit Rev Solid State Mater Sci. https://doi.org/10.1080/10408430903505036
153. Naidu PK, Pulagara NV, Dondapati RS (2014) Carbon nanotubes in engineering applications: a review. Prog Nanotechnol Nanomatpp https://doi.org/10.5963/pnn0304003

154. Varshney K (2014) Carbon nanotubes: a review on synthesis, properties and applications. Int J Eng Res Gen Sci 2:660-677

155. Kim JK, Shin JH, Lee JS, Hwang JH, Lee JH, Baek JE, Kim TG, Kim BW, Kim JS, Lee GH, Ahn K, Han SG, Bello D, Yu IJ (2016) 28-Day inhalation toxicity of graphene nanoplatelets in Sprague-Dawley rats. Nanotoxicology 10(7):891-901. https:// doi.org/10.3109/17435390.2015.1133865

156. Usenko CY, Harper SL, Tanguay RL (2007) In vivo evaluation of carbon fullerene toxicity using embryonic zebrafish. Carbon N Y 45(9):1891-1898. https://doi.org/10.1016/j.carbo n.2007.04.021

157. Revel M, Fournier M, Robidoux PY (2015) Single-walled carbon nanotubes toxicity to the freshwater amphipod Hyalella azteca: influence of sediment and exposure exposure duration.J Xenobiot. https://doi.org/10.4081/xeno.2015.5086

158. Youn S, Wang R, Gao J, Hovespyan A, Ziegler KJ, Bonzongo JC, Bitton G (2011) Mitigation of the impact of single-walled carbon nanotubes on a freshwater green algae: pseudokirchneriella subcapitata. Nanotoxicology. https://doi. org/10.3109/17435390.2011.562329

159. Couvreur P (1988) Polyalkylcyanoacrylates as colloidal drug carriers. Crit Rev Ther Drug Carr Syst 5(1):1-20

160. Cheng W, Zhou XF, Compton RG, Compton (2013) Electrochemical sizing of organic nanoparticles. Angew Chem Int Ed. https ://doi.org/10.1002/anie.201307653

161. Allouche J (2013) Synthesis of organic and bioorganic nanoparticles: an overview of the preparation methods. In: Nanomaterials: a danger or a promise? A chemical and biological perspective, Springer, London, pp 27-74

162. Subbiah R, Veerapandian M, Yun KS (2010) Nanoparticles: functionalization and multifunctional applications in biomedical sciences. Curr Med Chem 17(36):4559-4577

163. Behrens S (2011) Preparation of functional magnetic nanocomposites and hybrid materials: recent progress and future directions. Nanoscale 3:877-892. https://doi.org/10.1039/CONR0 0634C(Minireview)

164. Lard M, Bäckman J, Yakovleva M, Danielsson B, Hansson L-A (2010) Tracking the small with the smallest-using nanotechnology in tracking zooplankton. PLoS ONE 5(10):e13516. https ://doi.org/10.1371/journal.pone.0013516

165. Lynch I, Dawson KA, Linse S (2006) Detecting cryptic epitopes created by nanoparticles. Science STKE. https://doi. org/10.1126/stke.3272006pe14

166. Cedervall T, Lynch I, Foy M, Berggård T, Donnelly SC, Cagney G, Linse S, Dawson KA (2007) Detailed identification of plasma proteins absorbed to copolymer nanoparticles. Angew Chem Int Ed 46(30):5754-5756. https://doi.org/10.1002/anie.20070 0465

167. Lundqvist M, Stigler J, Elia G, Lynch I, Cedervall T, Dawson KA (2008) Nanoparticle size and surface properties determine the protein corona with possible implications for biological impacts. Proc Natl Acad Sci 105(38):14265-14270. https://doi. org/10.1073/pnas.0805135105

168. Lynch I, Salvati A, Dawson KA (2009) Protein-nanoparticle interactions: what does the cell see? Nat Nanotechnol 4(9):546-547. https://doi.org/10.1038/nnano.2009.248

169. Dell'Orco D, Lundqvist $M$, Oslakovic C, Cedervall T, Linse $S$ (2010) Modelling the time evolution of the nanoparticle-protein corona in a body fluid. PLoS ONE 5(6):e10949. https://doi. org/10.1371/journal.pone.0010949

170. Cabaleiro-Lago C, Quinlan-Pluck F, Lynch I, Lindman S, Minogue AM, Thulin E, Walsh DM, Dawson KA, Linse S (2008) Inhibition of amyloid beta protein fibrillation by polymeric nanoparticles. J 
Am Chem Soc 130(46):15437-15443. https://doi.org/10.1021/ ja8041806

171. Oslakovic C, Cedervall T, Linse S, Dahlbäck B (2012) Polystyrene nanoparticles affecting blood coagulation. Nanomedicine 8(6):981-986. https://doi.org/10.1016/j.nano.2011.12.001

172. Chang $C$ (2010) The immune effects of naturally occurring and synthetic nanoparticles. J Autoimmun 34(3):J234-J246. https ://doi.org/10.1016/j.jaut.2009.11.009

173. Klaine SJ, Alvarez PJJ, Batley GE, Fernandes TF, Handy RD, Lyon DY, Mahendra S, McLaughlin MJ, Lead JR, (2008) Nanomaterials in the environment: Behavior, fate, bioavailability, and effects. Environ Toxicol Chem. https://doi.org/10.1897/08-090.1

174. Domingos RF, Baalousha MA, Ju-Nam Y, Reid MM, Tufenkji N, Lead JR, Leppar GG, Wilkinson KJ (2009) Characterizing manufactured nanoparticles in the environment: multimethod determination of particle sizes. Environ Sci Technol 43(19):7277-7284. https://doi.org/10.1021/es900249m

175. Moore MN (2006) Do nanoparticles present ecotoxicological risks for the health of the aquatic environment? Environ Int 32(8):967-976. https://doi.org/10.1016/j.envint.2006.06.014

176. Oberdorster E (2004) Manufactured nanomaterials (fullerenes, C60) induce oxidative stress in the brain of juvenile largemouth bass. Environ Health Perspect 112(10):1058-1062

177. Nowack B, Bucheli TD (2007) Occurrence, behavior, and effects of nanoparticles in the environment. Environ Pollut. https://doi. org/10.1016/j.envpol.2007.06.006

178. DeMott WR (1986) The role of taste in food selection by freshwater zooplankton. Oecologia 69:334-340

179. DeMott WR (1995) The influence of prey hardness on Daphnia's selectivity for large prey. Hydrobiologia 307(1):127-138. https ://doi.org/10.1007/BF00032004

180. Bern L (1994) Particle selection over a broad size range by crustacean zooplankton. Freshw Biol. https://doi. org/10.1111/j.1365-2427.1994.tb00870.x

181. Baer A, Langdon C, Mills S, Schulz C, Hamre K (2008) Particle size preference, gut filling and evacuation rates of the rotifer Brachionus "Cayman" using polystyrene latex beads. Aquaculture. https://doi.org/10.1016/j.aquaculture.2008.06.020

182. Cedervall T, Hansson LA, Lard M, Frohm B, Linse S (2012) Food chain transport of nanoparticles affects behaviour and fat metabolism in fish. PLoS ONE 7(2):e32254. https://doi. org/10.1371/journal.pone.0032254

183. Thompson RC, Olsen $Y$, Mitchell RP, Davis A, Rowland SJ, John AWG, McGonigle D, Russell AE (2004) Lost at sea: where is all the plastic? Science 304:838. https://doi.org/10.1126/scien ce.1094559

184. Gregory MR (2009) Environmental implications of plastic debris in marine settings entanglement, ingestion, smothering, hangers-on, hitch-hiking, and alien invasions. Philos Trans R Soc Lond Ser 364(1526):2013-25. https://doi.org/10.1098/ rstb.2008.0265

185. Thompson R, Moore C, Andrady A, Gregory M, Takada H, Weisberg $S$ (2005) New directions in plastic debris. Science 310:1117. https://doi.org/10.1126/science.310.5751.1117b

186. Mattsson K, Ekvall MT, Hansson LA, Linse S, Malmendal A, Cedervall T (2014) Altered behavior, physiology and metabolism in fish exposed to polystyrene nanoparticles. Am Chem Soc 49(1):553-561. https://doi.org/10.1021/es5053655

187. Shokri N, Akbari Javar H, Fouladdel Sh, Khalaj A, Khoshayand MR, Dinarvand R (2011) Preparation and evaluation of poly (caprolactone fumurate) nanoparticles containing Doxorubicin HCl. Daru 19(1):12-22

188. Kateb B, Chiu K, Black KL, Yamamoto V, Khalsa B, Ljubimova JY, Ding H, Patil R, Portilla-Arias JA, Modo M, Moore DF, Farahani K, Okun MS, Prakash N, Neman J, Ahdoot D, Grundfest W, Nikzad S, Heiss JD (2011) Nanoplatforms for constructing new approaches to cancer treatment, imaging, and drug delivery: what should be the policy? Neuroimage 54:106-124. https:// doi.org/10.1016/j.neuroimage.2010.01.105

189. Mansour HM, Sohn M, Al-Ghananeem A, Deluca PP (2010) Materials for pharmaceutical dosage forms: molecular pharmaceutics and controlled release drug delivery aspects. Int J Mol Sci 11(9):3298-3322. https://doi.org/10.3390/ijms110932 98

190. Ludwig A (2005) The use of mucoadhesive polymers in ocular drug delivery. Adv Drug Deliv Rev 57(11):1595-1639. https:// doi.org/10.1016/j.addr.2005.07.005

191. Luppi B, Bigucci F, Corace G, Delucca A, Cerchiara T, Sorrenti M, Catenacci L, Di Pietra AM, Zecchi V (2011) Albumin nanoparticles carrying cyclodextrins for nasal delivery of the antiAlzheimer drug tacrine. Eur J Pharm Sci 44(4):559-565. https ://doi.org/10.1016/j.ejps.2011.10.002

192. Gelperina S, Kisich K, Iseman MD, Heifets L (2005) The potential advantages of nanoparticle drug delivery systems in chemotherapy of tuberculosis. Am J Respir Crit Care Med 172(12):1487-1490. https://doi.org/10.1164/rccm.20050 4-613PP

193. Akamatsu K, Takei S, Mizuhata M, Kajinami A, Deki S, Takeoka S, Fujii M, Hayashi S, Yamamoto K (2000) Preparation and characterization of polymer thin films containing silver and silver sulfide nanoparticles. Thin Solid Films. https://doi.org/10.1016/ S0040-6090(99)00684-7

194. Elzoghby AO, Abd-Elwakil MM, Abd-Elsalam K, Elsayed MT, Hashem Y, Mohamed O (2016) Natural polymeric nanoparticles for brain-targeting: implications on drug and gene delivery. Curr Pharm Des 22(22):3305-3323

195. Nasir A, Kausar A, Younus A (2015) A review on preparation, properties and applications of polymeric nanoparticle-based materials. Polym-Plast Technol Eng. https://doi. org/10.1080/03602559.2014.958780

196. Schmid G (2004) Nanoparticles: from theory to applications. Wiley-VCH, Weinheim. https://doi.org/10.1080/10426 914.2012.663137

197. Wang D, He J, Rosenzweig N, Rosenzweig Z (2004) Superparamagnetic $\mathrm{Fe} 2 \mathrm{O} 3$ Beads - CdSe/ZnS quantum dots core - shell nanocomposite particles for cell separation. Nano Lett. https ://doi.org/10.1021/nl035010n

198. Jang JS, Oh JH (2002) Novel crystalline supramolecular assemblies of amorphous polypyrrole nanoparticles through surfactant templating. Chem Commun. https://doi.org/10.1039/ B207744M

199. Fudouzi $\mathrm{H}, \mathrm{Xia} Y$ (2003) Photonic papers and inks: color writing with colorless materials. Adv Mater. https://doi.org/10.1002/ adma.200304795

200. Brahim S, Narinesingh D, Elie GA (2001) Amperometric determination of cholesterol in serum using a biosensor of cholesterol oxidase contained within a polypyrrole hydrogel membrane. Anal Chim Acta. https://doi.org/10.1016/S0003-2670(01)01321 $-6$

201. Kvavadze E, Bar-Yosef O, Belfer-Cohen A, Boaretto E, Jakeli N, Matskevich Z (2009) 30,000-year-old wild flax fibers. Science 325:1359. https://doi.org/10.1126/science.1175404

202. Kang B, Opatz T, Landfester K, Wurm FR (2015) Carbohydrate nanocarriers in biomedical applications: functionalization and construction. R Soc Chem 44:8301-8325. https://doi. org/10.1039/C5CS00092K

203. Kennedy DC, Orts-Gil G, Lai C, Mller L, Haase A, Luch A, Seeberger PH (2014) Carbohydrate functionalization of silver nanoparticles modulates cytotoxicity and cellular uptake. J Nanobiotechnol 12:59. https://doi.org/10.1186/s12951-014-0059-z

204. Hajiyeva FV, Ramazanov MA, Maharramov AM, Hasanova UA, Rahimli AM (2017) Influence temperature time mode of 
crystallization on the structure and properties of nanocomposites based on polyvinylidene fluoride (PVDF) and zirconium oxide nanoparticles (ZrO2). J Optoelectron Biomed Mater 9:1-7

205. Etheridge ML, Campbell SA, Erdman AG, Haynes CL, Wolf SM, McCullough J (2013) The big picture on small medicine: the state of nanomedicine products. Nanomedicine 9(1):1-14. https://doi.org/10.1016/j.nano.2012.05.013

206. Maharramov AM, Ramazanov MA, Ahadova Al, Kloor M, Kopitz J, Doeberitz MVK, Shabanov AL, Eyvazova QM, Agamaliyev ZA, Hajiyeva FV, Veliyeva SB, Hasanova UA (2014) Preparation of 2-Deoxy-D-Glucose coated spio nanoparticles and characterization of their physical, chemical and biological properties. Dig J Nanomater Biostruct 9:1461-1469

207. Gottschalk F, Nowack B (2011) The release of engineered nanomaterials to the environment. Environ Monit 13(5):1145-1155. https://doi.org/10.1039/c0em00547a

208. Maurer-Jones MA, Gunsolus IL, Murphy CJ, Haynes CL (2014) Toxicity of engineered nanoparticles in the environment. Anal Chem 85(6):3036-3049. https://doi.org/10.1021/ac303636s

209. Rossi G, Barnoud J, Monticelli L (2014) Polystyrene nanoparticles perturb lipid membranes. Article J Phys Chem 5(1):241246. https://doi.org/10.1021/jz402234c

210. Kashiwada S (2006) Distribution of nanoparticles in the seethrough medaka (Oryzias latipes). Environ Health Perspect 114(11):1697-1702. https://doi.org/10.1289/ehp.9209

211. Smith CJ, Shaw BJ, Handy RD (2007) Toxicity of single walled carbon nanotubes to rainbow trout (Oncorhynchus mykiss): respiratory toxicity, organ pathologies, and other physiological effects. Aquat Toxicol 82(2):94-109. https://doi.org/10.1016/j. aquatox.2007.02.003

212. Fahmy TM, Fong PM, Park J, Constable T, Saltzman WM (2007) Nanosystems for simultaneous imaging and drug delivery to T Cells. AAPS J 9(2):E171-E180. https://doi.org/10.1208/aapsj 0902019

213. Jain K, Jain NK (2014) Surface engineered dendrimers as antiangiogenic agent and carrier for anticancer drug: dual attack on cancer. J Nanosci Nanotechnol 14(7):5075-5087

214. Li Y, Cheng Y, Xu T (2007) Design, synthesis and potent pharmaceutical applications of glycodendrimers: a mini review. Curr Drug Discov Technol 4(4):246-254

215. Jansen JF, de Brabander-van den Berg EM, Meijer EW (1994) Encapsulation of guest molecules into a dendritic box. Science 266(5188):1226-1229. https://doi.org/10.1126/scien ce.266.5188.1226

216. Kaur D, Jain K, Mehra NK, Kesharwani P, Jain NK (2016) A review on comparative study of PPI and PAMAM dendrimers. J Nanopart Res 18:146

217. Wu J, Huang W, He Z (2013) Dendrimers as carriers for siRNA delivery and gene silencing: a review. Sci World J. https://doi. org/10.1155/2013/630654

218. Volcke C, Pirotton S, Grandfils Ch, Humbert C, Thiry PA, Ydens I, Dubois P, Raes M (2006) Influence of DNA condensation state on transfection efficiency in DNA/polymer complexes: an AFM and DLS comparative study. J Biotechnol 125(1):11-21. https:// doi.org/10.1016/j.jbiotec.2006.02.010

219. Jain K, Kesharwani P, Gupta U, Jain NK (2010) Dendrimer toxicity: let's meet the challenge. Int J Pharm 394(1-2):122-142. https://doi.org/10.1016/j.ijpharm.2010.04.027

220. Abbasi E, Aval SF, Akbarzadeh A, Milani M, Nasrabadi HT, Sang WJ, Hanifehpour Y, Nejati-Koshki K, Pashaei-AsI R (2014) Dendrimers: synthesis, applications, andproperties. Nanoscale Res Lett 9:247. https://doi.org/10.1186/1556-276X-9-247

221. Akbarzadeh A, Khalilov R, Mostafavi E, Annabi N, Abasi E, Kafshdooz T, Herizchi R, Kavetskyy T, Saghfi S, Nasibova A, Davaran S (2018) Role of dendrimers in advanced drug delivery and biomedical applications: a review. Exp Oncol 40(3):178-183
222. Harper SL, Carriere JL, Miller JM, Hutchison JE, Maddux BL, Tanguay RL (2011) Systematic evaluation of nanomaterial toxicity: utility of standardized materials and rapid assays. ACS Nano 5(6):4688-4697. https://doi.org/10.1021/nn200 $546 \mathrm{k}$

223. Truong L, Harper S, Tanguay R (2001) Evaluation of embryotoxicity using the zebrafish model. Drug Saf 691:271-279. https:// doi.org/10.1007/978-1-60761-849-2_16

224. Pryor JB, Harper BJ, Harper SL (2014) Comparative toxicological assessment of PAMAM and thiophosphoryl dendrimers using embryonic zebrafish. Int J Nanomed 9:1947-1956. https://doi. org/10.2147/IJN.S60220

225. Heiden TC, Dengler E, Kao WJ, Heideman W, Peterson RE (2007) Developmental toxicity of low generation PAMAM dendrimers in zebrafish. Toxicol Appl Pharmacol 225(1):70-79. https://doi. org/10.1016/j.taap.2007.07.009

226. Kitchens KM, El-Sayed ME, Ghandehari H (2005) Transepithelial and endothelial transport of poly (amidoamine) dendrimers. Adv Drug Deliv Rev 57(15):2163-2176. https://doi. org/10.1016/j.addr.2005.09.013

227. Dong Z, Hamid KA, Gao Y, Lin Y, Katsumi H, Sakane T, Yamamoto $A$ (2011) Polyamidoamine dendrimers can improve the pulmonary absorption of insulin and calcitonin in rats. J Pharm Sci 100(5):1866-1878. https://doi.org/10.1002/jps.22428

228. Chen HT, Neerman MF, Parrish AR, Simanek EE (2004) Cytotoxicity, hemolysis, and acute in vivo toxicity of dendrimers based on melamine, candidate vehicles for drug delivery. J Am Chem Soc 126(32):10044-10048. https://doi.org/10.1021/ja048548j

229. Rittner K, Benavente A, Bompard A, Jacobs E (2002) New basic membrane-destabilizing peptides for plasmid-based gene delivery in vitro and in vivo. Mol Ther 5(2):104-114. https:// doi.org/10.1006/mthe.2002.0523

230. Rana S, Kalaichelvan PT (2013) Ecotoxicity of nanoparticles. ISRN Toxicol. https://doi.org/10.1155/2013/574648

231. Bhatia R, Viswanathan PN, Kakkar P (1991) Liposomes as a model for studying the effect of UV radiations on biomembranes. J Microencapsul 8(3):349-357. https://doi. org/10.3109/02652049109069561

232. Mozafari MR, Johnson C, Hatziantoniou S, Demetzos C (2008) Nanoliposomes and their applications in food nanotechnology. J Liposome Res 18(4):309-327. https://doi.org/10.1080/08982 100802465941

233. Duncan R, Izzo L (2005) Dendrimer biocompatibility and toxicity. Adv Drug Deliv Rev 57(15):2215-2237. https://doi. org/10.1016/j.addr.2005.09.019

234. Sallovitz JM, Zonco Menghini MI, Lanusse CE (1998) Impact of liposomes as delivery systems in veterinary medicine. Vet Res 29(5):409-430

235. Monteiro N, Martins A, Reis RL, Neves NM (2014) Liposomes in tissue engineering and regenerative medicine. J R Soc Interface. https://doi.org/10.1098/rsif.2014.0459

236. Lindner LH, Hossann $M$ (2010) Factors affecting drug release from liposomes. Curr Opin Drug Discov Devel 13(1):111-123

237. Akbarzadeh A, Rezaei-Sadabady R, Davaran S, Joo SW, Zarghami N, Hanifehpour Y, Samiei M, Kouhi M, NejatiKoshki K (2013) Liposome: classification, preparation, and applications. Nanoscale Res Lett 8(1):102. https://doi. org/10.1186/1556-276X-8-102

238. Giannoni P, Hunziker EB (2003) Release kinetics of transforming growth factor-beta 1 from fibrin clots. Biotechnol Bioeng. https ://doi.org/10.1002/bit.10639

239. Brugnoli-Olivera $E$, Díaz-Ferguson $E$, Delfino-Machin $M$, Morales-Ramírez A, Arosemena AD (2004) Composition of the zooplankton community, with emphasis in copepods, in Punta Morales, Golfo de Nicoya, Costa Rica. Rev Biol Trop 52(4):897-902 
240. Beaugrand G, Brander KM, Alistair Lindley J, Souissi S, Reid PC (2003) Plankton effect on cod recruitment in the North Sea. Nature 426(6967):661-664. https://doi.org/10.1038/natur e02164

241. Buttino I, De Rosa G, Carotenuto Y, lanora A, Fontana A, Quaglia F, La Rotonda MI, Miralto A (2006) Giant liposomes as delivery system for ecophysiological studies in copepods. J Exp Biol 209(Pt 5):801-809. https://doi.org/10.1242/jeb.02068

242. Barr Y, Helland S (2007) A simple method for mass-production of liposomes, in particular large liposomes, suitable for delivery of free amino acids to filter feeding zooplankton. J Liposome Res 17(2):79-88

Publisher's Note Springer Nature remains neutral with regard to jurisdictional claims in published maps and institutional affiliations. 